\title{
Lexicography in a Multilingual South Africa
}

Abstract: On 12 April 1996 the State Language Services organized a language planning seminar, Lexicography as a Financial Asset in a Multilingual South Africa, held at the Bureau of the Woordeboek van die Afrikaanse Taal in Stellenbosch. A special feature of this workshop was the active participation not only of linguists and lexicographers involved in the academic and practical side of producing dictionaries, but also of those with commercial interests in this area, viz. publishers and marketers of dictionaries. An important part of the seminar was the contributions on the lexicographic needs of each of the eleven official languages of the Republic of South Africa.

This seminar was followed by a consultative meeting for stakeholders arranged by the Pan South African Language Board (PANSALB) on 31 October 1997 in Johannesburg. The purpose of the meeting was to explain to participants the state of the legislation concerning lexicography units, to inform participants of the language plan for the Republic of South Africa and the role of lexicography in it, to make participants aware of the preparation needed to establish a lexicography unit, and to obtain the view of participants regarding important lexicographic matters by means of a questionnaire and discussions.

This meeting was an important precursor to two further meetings which PANSALB arranged in the Johannesburg Civic Centre, namely the Lexicographic Meeting of the Existing Lexicographic Units of South Africa on 19 and 20 March 1998 and the Lexicographic Meeting of the Languages which do not already have a Lexicographic Unit on 14 and 15 May 1998. The delegates participated in establishing norms for the recognition of existing and new lexicography units, and for the provision of personnel to, and for the state subsidisation of lexicography units. Regulations for the lexicography units were also discussed.

The papers presented at these two meetings provide a synopsis of the state of lexicography in the different official languages of the Republic of South Africa. The assignment for the first occasion was to outline the mission, history and present situation of the existing units, namely of Afrikaans, English, isiNdebele, Sepedi, isiXhosa and isiZulu. The assignment for the second occasion was to delineate the state of lexicography in those languages which do not have lexicography units, namely Sesotho, Setswana, siSwati, Tshivenda and Tsonga.

Adapted and updated extracts from the documentation of these meetings are published here with the kind permission of PANSALB and of the presenters of the different papers.

These are preceded by an exposition of the procedure for the establishing of the lexicography units for the eleven official languages of the Republic of South Africa.

PANSALB was established in 1995 in terms of the Pan South African Language Board Act (No. 59 of 1995). To make provision for, inter alia, the creation of lexicography units by PANSALB, the Pan South African Language Board Amendment Act (No. 10 of 1999) was assented to this year. The aims of PANSALB are:

(a) to promote respect for and ensure the implementation of the following principles: 
(i) the creation of conditions for the development and for the promotion of the equal use and enjoyment of all the official South African languages;

(ii) the extension of those rights relating to language and the status of languages which before 27 April 1994 were restricted to certain regions;

(iii) the prevention of the use of any language for the purposes of exploitation, domination or division;

(iv) the promotion of -

(aa) multilingualism; and

(bb) the provision of translation and interpreting facilities;

(v) the fostering of respect for languages spoken in the Republic other than the official languages, and the encouragement of their use in appropriate circumstances; and

(vi) the non-diminution of rights relating to language and the status of languages existing before 27 April 1994;

(b) to further the development of the official South African languages;

(c) to promote respect for and the development of other languages used by communities in South Africa, and languages used for religious purposes;

(d) to promote knowledge of and respect for the provisions and principles of the Constitution relating directly or indirectly to language matters;

(e) to promote respect for multilingualism in general; and

(f) to promote the utilisation of South Africa's language resources.

Keywords: PANSALB, LEXICOGRAPHY UNITS, PAN SOUTH AFRICAN LANGUAGE BOARD ACT, 1995, PAN SOUTH AFRICAN LANGUAGE BOARD AMENDMENT ACT, 1998, AFRILEX, BUREAU OF THE WOORDEBOEK VAN DIE AFRIKAANSE TAAL, DICTIONARY UNIT FOR ISINDEBELE, DICTIONARY UNIT FOR SOUTH AFRICAN ENGLISH, NORTHERN SOTHO DICTIONARY UNIT, XHOSA DICTIONARY PROJECT, ZULU DICTIONARY PROJECT, SESOTHO LEXICOGRAPHY, SETSWANA LEXICOGRAPHY, SISWATI LEXICOGRAPHY, TSHIVENDA LEXICOGRAPHY, TSONGA LEXICOGRAPHY

Opsomming: Leksikografie in 'n meertalige Suid-Afrika. Op 12 April 1996 het die Staatstaaldiens ' $n$ taalbeplanningseminaar, Lexicography as a Financial Asset in a Multilingual South Africa, gereël wat by die Buro van die Woordeboek van die Afrikaanse Taal op Stellenbosch gehou is. ' $n$ Besondere kenmerk van dié seminaar was die deelname nie net van taalkundiges en leksikograwe betrokke by die akademiese en praktiese kant van die opstel van woordeboeke nie, maar ook diegene met kommersiële belange op hierdie gebied, nl. die uitgewers en bemarkers van woordeboeke. 'n Belangrike deel van dié seminaar was die bydraes oor die leksikografiese behoeftes van elkeen van die elf amptelike tale van die Republiek van Suid-Afrika.

Hierdie seminaar is gevolg deur 'n raadplegende vergadering gereël deur die Pan-Suid-Afrikaanse Taalraad (PANSAT) met belanghebbendes op 31 Oktober 1997 in Johannesburg. Die doel van die vergadering was om aan deelnemers die stand van die wetgewing betreffende leksikografie-eenhede te verduidelik, om deelnemers in te lig oor die taalplan van die Republiek van SuidAfrika en die rol van die leksikografie daarin, om deelnemers bewus te maak van die voorbereiding nodig om ' $n$ leksikografie-eenheid op te rig, en om die opvattings van deelnemers te 
verkry betreffende belangrike leksikografiese aangeleenthede met behulp van 'n vraelys en besprekings.

Hierdie byeenkoms was in belangrike voorloper van twee verdere byeenkomste wat deur PANSAT in die Burgersentrum in Johannesburg gereël is, $\mathrm{nl}$. Lexicographic Meeting of the Existing Lexicographic Units of South Africa op 19 en 20 Maart 1998 en Lexicographic Meeting of the Languages which do not already have a Lexicographic Unit op 14 en 15 Mei 1998. Die afgevaardigdes het deelgeneem aan die bepaling van norme vir die erkenning van bestaande en nuwe leksikografie-eenhede, en vir die voorsiening van personeel aan en staatsubsidiëring van leksikografie-eenhede. Bepalings vir die leksikografie-eenhede is ook bespreek.

Die referate wat by hierdie twee byeenkomste gehou is, gee ' $n$ oorsig van die stand van die leksikografie in die verskillende amptelike tale in die Republiek van Suid-Afrika. Die opdrag vir die eerste geleentheid was om die missie, geskiedenis en huidige omstandighede van die bestaande eenhede uiteen te sit, nl. Afrikaans, Engels, isiNdebele, Sepedi, isiXhosa en isiZulu. Die opdrag vir die tweede geleentheid was om die stand van die leksikografie te skets in die tale wat nog nie leksikografiese eenhede het nie, nl. Sesotho, Setwana, siSwati, Tshivenda en Tsonga.

Aangepaste en bygewerkte uittreksels uit die dokumentasie van die byeenkomste word hier gepubliseer met die vriendelike vergunning van PANSAT en die aanbieders van die onderskeie referate.

Hulle word voorafgegaan deur 'n uiteensetting van die prosedure vir die instelling van die leksikografie-eenhede vir die elf amptelike tale van die Republiek van Suid-Afrika.

PANSAT het in 1995 tot stand gekom kragtens die Wet op die Pan-Suid-Afrikaanse Taalraad (No. 59 van 1995). Om onder andere voorsiening te maak vir die stigting van leksikografie-eenhede deur PANSAT is die Wysigingswet op die Pan-Suid-Afrikaanse Taalraad (No. 10 van 1999) vanjaar aangeneem. Die oogmerke van PANSAT is:

(a) om respek te bevorder vir, en die implementering te verseker van die volgende beginsels:

(i) die skepping van toestande vir die ontwikkeling en vir die bevordering van die gelyke gebruik en benutting van al die amptelike Suid-Afrikaanse tale;

(ii) die uitbreiding van daardie regte met betrekking tot taal en die status van tale wat voor 27 April 1994 tot sekere streke beperk was;

(iii) die voorkoming van die gebruik van enige taal vir die doeleindes van uitbuiting, oorheersing of verdeling:

(iv) die bevordering van -

(aa) veeltaligheid; en

(bb) die voorsiening van vertalings-en tolkfasiliteite;

(v) die kweek van respek vir ander tale, benewens die amptelike tale, wat in die Republiek gepraat word, en die aanmoediging van die gebruik daarvan in gepaste omstandighede; en

(vi) die nievermindering van regte met betrekking tot taal en die status van tale wat voor 27 April 1994 bestaan het;

(b) om die uitbouing van die amptelike Suid-Afrikaanse tale na te streef;

(c) om respek vir en die ontwikkeling van ander tale wat deur gemeenskappe in Suid-Afrika gebruik word, asook tale wat vir godsdiensdoeleindes gebruik word, te bevorder; 
(d)

om kennis van en respek vir die bepalings en beginsels van die Grondwet wat regstreeks of onregstreeks betrekking het op taalaangeleenthede, te bevorder;

(e) om respek vir veeltaligheid in die algemeen te bevorder; en

(f) om die benutting van Suid-Afrika se taalhulpbronne te bevorder.

Sleutelwoorde: PANSAT, LEKSIKOGRAFIE-EENHEDE, WET OP DIE PAN-SUID-AFRIKAANSE TAALRAAD, 1995, WYSIGINGSWET OP DIE PAN-SUID-AFRIKAANSE TAALRAAD, 1999, AFRILEX, BURO VAN DIE WOORDEBOEK VAN DIE AFRIKAANSE TAAL, DICTIONARY UNIT FOR SOUTH AFRICAN ENGLISH, SEPEDI WOORDEBOEKPROJEK, WOORDEBOEKEENHEID VIR ISINDEBELE, XHOSA WOORDEBOEKPROJEK, ZULU WOORDEBOEKPROJEK, SESOTHO LEKSIKOGRAFIE, SETSWANA LEKSIKOGRAFIE, SISWATI LEKSIKOGRAFIE, TSHIVENDA LEKSIKOGRAFIE, TSONGA LEKSIKOGRAFIE

\section{The National Lexicography Units - Existing and Prospective*}

M.B. Kumalo, Chairperson, Subcommittee: Lexicography and Terminology of the Pan South African Language Board, Pretoria, Republic of South Africa

\section{Introduction}

From a purely political point of view, there has been inequality and inequity in the funding of the development and promotion of a section of South African languages due to the laws that prevailed in the past. It is fitting, therefore, that the whole debate on the lexicography units is brought into its correct perspective, that is: lexicographical rather than political, at least now that there has been change in government policy. An opportune moment has now presented itself to redress the failures and shortcomings of the past.

Those in the Pan South African Language Board (PANSALB) who have been entrusted with this responsibility are determined to see to it that justice is done to everybody's satisfaction without diminishing existing benefits, and similarly, without short-changing previously deprived languages. Together and without anyone prescribing to the others, success is assured because this is a joint venture. PANSALB from its side shall facilitate movement and leave direction and pace to the native speakers and their academic technicians. PANSALB shall not impose itself on the units, but shall make it possible for them to take responsible decisions relevant to their specific and individual needs.

This is a slightly adapted and updated version of a keynote address given at the Third International Conference of the African Association for Lexicography, held at the University of Potchefstroom for CHE, Potchefstroom, 29-30 June 1998. 


\subsection{National Lexicography Units Bill}

The National Lexicography Units Bill which was on the verge of being passed as an Act of Parliament in 1997, was a controversial document. Some lexicographers were in fact guilty of already regarding it as a legal personality rather than as a document to be commented upon. However, it has contributed strongly to the debate and has alerted many to the possibilities and opportunities available. It highlighted the fact that there was one-sidedness and favouritism in funding and that equity was a necessity and a requirement to be striven towards. It also pointed out that all languages would be treated equally and given the same opportunity for advancement and that preferential treatment would no longer be given to any one language only. That disclosure was a positive indicator.

There were claims and counterclaims that the Bill had been sufficiently canvassed among those who were directly or indirectly affected as practising lexicographers in their various languages. As comments poured in, many of them very positive, however, the Minister found it expedient to withdraw it because of the impending establishment of the Commission for the Promotion and Protection of the Rights of Cultural, Religious and Linguistic Communities, whose powers would overlap with those of PANSALB which had been established under the Interim Constitution. Since PANSALB had a clear constitutionally mandated role in language development, the Minister found it important to withdraw the National Lexicography Units Bill with a view of possibly assigning the establishment of the National Lexicography Units to PANSALB. Great uncertainty followed until it became evident that its functions would be subsumed under PANSALB.

More to-ing and fro-ing ensued. The debate was reopened.

\subsection{Subsuming of the National Lexicography Units Bill into PANSALB}

The new constitution stipulates that the function of PANSALB is language development and the promotion of multilingualism. It was therefore argued that the subsuming of the National Lexicography Units Bill under PANSALB was in line and in keeping with this central function. To this end, several meetings took place between PANSALB and the Department of Arts, Culture, Science and Technology on the one hand, and between PANSALB and the Language Subcommittee of the Parliamentary Portfolio Committee on the other. A tripartite meeting between the Department, PANSALB and the Portfolio Language Subcommittee was held on Monday 4 May 1998 to expedite and finalise this matter. Documents were exchanged and further discussions took place, resulting in the draft Pan South African Language Board Amendment Bill, 1998. The Portfolio Committee submitted about six amendments and PANSALB about twenty. Although every member of PANSALB was in favour of the establishment and development of the different lexicography units, not 
every member was in agreement on or in favour of the manner of implementation. One member of PANSALB resigned as a result. The scepticism mainly concerned the question of funding. At that stage it was not very clear whether the units will receive funding directly from PANSALB or directly from Parliament. Section 10(1)(b) of the draft Regulations for the National Lexicography Units on the financing of a unit reads: "moneys appropriated by Parliament for the purpose of the unit". These regulations are still in draft form and have not as yet been approved by the Minister.

The Pan South African Language Board Amendment Bill, 1998, was assented to on 14 April 1999 as the Pan South African Language Board Amendment Act, Act No. 10 of 1999.

The preamble of the draft Pan South African Language Board Amendment Bill, 1998, reads as follows: "To amend the PAN SOUTH AFRICAN LANGUAGE BOARD ACT, 1995, to provide for National Lexicography Units, to bring the act in line with the provisions of the Constitution of the Republic of South Africa, 1996, and for matters connected therewith." The relevant parts in the preamble to the Pan South African Language Board Amendment Act, 1999, have been changed to: "To amend the Pan South African Language Board Act, $1995, . . . ;$ to establish lexicography units; ... to effect certain consequential and technical amendments necessitated by the supersedence of the Constitution of the Republic of South Africa, 1993, by the Constitution of the Republic of South Africa, 1996." As the units are meant to redress the shortcomings of the past, there was a need for a paradigm shift in light of the new Constitution.

To that effect, an addition was made to the powers and functions of PANSALB in Section $8(8)$ (c) of the draft Bill, which stipulates that the Board shall establish "national lexicographic units for each of the official languages of South Africa". The relevant section in the Act states that the Board shall establish "units to operate as companies limited by guarantee under section 21 of the Companies Act, 1973 (Act No. 61 of 1973), and shall allocate funds to the units for the fulfilment of their functions". Nowhere else does the draft Bill or the Act refer to these units.

However, it is important to note that the intention is to empower PANSALB to establish national lexicography units, and not to control or regulate them. In other words, PANSALB is to act as a facilitator only. It will not run the units. It is also obvious that PANSALB will have no authority whatsoever over the administration of the new units, let alone over already existing units, because each unit will have its own management committee of nine members. There seems to be a misunderstanding, deliberate or not, regarding the subsuming of the lexicographic functions of the National Lexicography Units Bill and the establishment of the units by PANSALB. The Bill was intended to establish the units, this function is now being subsumed under PANSALB.

According to Section 5 of the draft Regulations for the National Lexicography Units, each management committee shall, in addition to its other functions, 
(a) formulate and ratify the policy to be followed in order to achieve the objectives of its unit;

(b) govern and advise its unit in accordance with the resources at its disposal;

(c) decide from time to time about matters relating to the publishing, printing and marketing of the dictionaries and products of its unit; and

(d) determine from time to time the number of review, gift, working and other copies of products of its unit to be made available free of charge.

Each unit will have its own full-time staff under the supervision of an editor-inchief, who will be accountable to the management committee.

These draft regulations have been circulated and discussed at the three workshops organised by the PANSALB Lexicography and Terminology Subcommittee on 31 October 1997, 19 and 20 March 1998 and 13 and 14 May 1998.

The status of the various units, when all have finally been established, will be equal in so far as provisioning is concerned. There is no doubt, however, that even if that is the case, the Bureau of the Woordeboek van die Afrikaanse Taal, and to a great extent the Dictionary Unit for South African English, will remain above the others for a long time to come. The currently ongoing dictionary projects are funded by various institutions. The Department of Arts, Culture, Science and Technology finances the Woordeboek van die Afrikaanse Taal as well as the Dictionary for South African English. Some public funds are also made available to support other lexicography projects indirectly through university funding, viz., isiNdebele, isiXhosa, isiZulu and Sepedi. It remains to be seen as to how the available funds will be shared among all the units in future.

Another point that needs to be addressed, is the involvement of AFRILEX in the affairs of the lexicography units. A question has also been posed as to the significance of representatives from existing units attending workshops with units that are still under discussion. A simple answer to that is the cliché: There is no need to reinvent the wheel. One is inclined to support and agree with $\mathrm{Mr}$ Bernd Schulz's maxim enunciated by himself on 31 October 1997 that "from diversity comes strength: linguistic diversity, training diversity, management diversity". There should be moved away "from prescriptive either/ors to inclusive both/ands".

Already, representatives of the envisaged units have benefited tremendously from the seminars and workshops that have been offered since 1996, facilitated by both AFRILEX and by the experienced and well-funded units. Even if there is not anything linguistically called co-operative lexicography, cooperation is going to play a major role in all the units in future. The stage has now been reached where all languages will enjoy equality, although qualified, so it is important that all should work together in diversity and to become unified in diversity. 
All units are to be autonomous and cannot be dictated to from outside. All units will have the power to decide for themselves what it is they wish to achieve and how to achieve it. Isolation will impoverish perpetrators thereof. There is no need therefore to cherish fear of domination.

The important role to be played by AFRILEX, an association of professionals, cannot be overemphasised. So long as it exists, AFRILEX will be in a position to offer guidance, training, etc., while management committees, by the nature of their composition, cannot have the same expertise and capacity. All units will need each other as they have already shown unofficially. This mutual need is not, has not and can still not be imposed - but it is there. It is going to grow when the units begin to share the same major source of funding. The units of the previously marginalised and disadvantaged languages will require propping-up because of historical reasons. There are not enough sufficiently trained African lexicographers yet.

After a unit has been established, it will take leave of PANSALB and can no longer rely on PANSALB to assist it in any way whatsoever (unless in so far as funding is channelled through PANSALB), because it would then be autonomous and, hopefully, self-sufficient.

Whereas the majority of existing lexicography units are presently involved in the compilation of monolingual dictionaries, new units will, like the isiXhosa unit, have the advantage of exploring other options. The scope is very wide and deep.

\section{Conclusion}

PANSALB has specific responsibilities regarding the establishment of the lexicography units. These responsibilities can be summarised as follows:

(a) to finalise the norms in terms of which the approval of lexicography units will take place;

(b) to assist with the formulation of the regulations in terms of which the lexicography units will be managed;

(c) to submit the norms and regulations to legal representatives for preparation and publication in the Government Gazette and Provincial Gazettes;

(d) to invite the controlling bodies of existing lexicography units to seek approval in accordance with the norms and regulations;

(e) to consider ways in which languages which do not have lexicography units should seek approval;

(f) to inform approved units of the matter, and

(g) that once a unit has been approved, to pay immediate attention to the following matters:

(i) to decide on the seat of each unit in consultation with the stakeholders in the particular language (Section 1(2)); 
(ii) to determine the name of the unit in consultation with the relevant management committee (Section 3); and

(iii) to form a management committee and to appoint an editor-in-chief (Section 4(1)(a), (c), (d), (e), (f), (g), (h), and Section 9(1)).

It is necessary to co-operate and draw from available expertise and resources. It is necessary to understand that this will in no way undermine the independence and autonomy, nor the self-assertiveness of any unit. Instead, the opposite is likely to be true.

\title{
Bureau of the Woordeboek van die Afrikaanse Taal
}

\author{
B.P.D. Gabriels, A.E. Cloete and W.F. Botha, Coeditors, Bureau of the
}

Woordeboek van die Afrikaanse Taal, Stellenbosch, Republic of South Africa

\section{Aim and Task}

In 1989 the Bureau adopted a management system based on a process of intensive strategic planning, amongst other reasons to streamline its activities. When the planning committee formulated a mission statement for the Bureau, it based it on two cornerstones, namely its aim and its task, as well as all activities emanating from the aim (the ideals and aspirations of the founders of the Bureau), and all the activities which it was expected to perform and promote, as set out in the relevant legislature. Consequently, all the activities of the Bureau are driven and directed by its aim and task

The aim of the Bureau of the WAT is to serve the Afrikaans language and its users, as well as lexicography in general. The users of the Afrikaans language include all geographical, social, economic, cultural and professional groupings and standings of the Afrikaans-speaking community. Flowing from the aim, the task of the Bureau is:

- To continue with the compilation of the WAT, to complete it as soon as possible and to revise and improve the dictionary from time to time.

This, as the primary line function of the Bureau, will firstly be made possible by the continuous representative and comprehensive collection of the vocabulary of the Afrikaans language in all its variations, and the arrangement and storage thereof in a lexicographically workable form. In the second place, it will be made possible by editing the collected material according to scientifically established lexicographic principles in the form of an authoritative, user-friendly, synchronic, and explanatory dictionary in consecutive volumes in alphabetical order. 
- To grant controlled access to the language, material and resources of the Bureau to bona fide researchers and to answer linguistic enquiries.

- To establish, with the assistance of external authors, appropriate lexicographic products for the different languages of South Africa.

- To produce the WAT and its satellite publications cost-effectively.

This means that the printing and binding of the different volumes of the WAT and other publications should be done as quickly and as economically as possible, without sacrificing quality and appearance.

- To market these products dynamically and economically.

The Bureau will achieve this by stimulating the target market by innovative professional advertisements and publicity, aimed at maximum sales.

- To act as a growth point and stimulus for lexicographic activities and metalexicographic reflection.

- To liaise with South African and foreign lexicographic and other linguistic institutions with a view to exchanging lexicographic knowledge, information and publications.

- To contribute to lexicographic theory and practice in the form of scientific publications.

- To assist in raising the general level of lexicography, especially in Africa, through co-operation with other dictionary projects.

- To play an active role in removing inequalities in lexicography through training and the creation of jobs.

- To contribute to the establishment and development of South African lexicography in support of the aims of the Pan South African Language Board.

- To strive for need directedness, quality and the unity of character in its activities and products.

Against the backdrop of current developments in the field of lexicography, the mission of the Bureau will have to be reviewed. As more and more lexicography units are coming into being, the Bureau will in some respects readjust and redefine the angle of its partnership in order to be of prime service to South African lexicography as a whole.

The Bureau is unreservedly committed to playing a prominent role in the promotion and development of a culture of co-operative lexicography in all South African languages and within the broader African context.

\section{Establishment and Progress}

The history of the WAT started in 1920 when Prof. J.J. Smith advocated the compilation of a bilingual dictionary and the collection of the Afrikaans vocabulary, with a view to the compilation of a explanatory monolingual Afrikaans dictionary in the Afrikaans newspaper Die Burger. Five years later a joint 
committee of both houses of Parliament recommended the compilation of a complete and authoritative dictionary, with State support.

In 1926, co-operation between Prof. Smith, the Nasionale Pers and the University of Stellenbosch was ensured by formal contracts. Work on the dictionary was started in Cape Town. At that stage, the idea was that Prof. Smith would compile a dictionary similar to the Dutch Van Dale, in other words a standard descriptive dictionary, which was to be completed within three years. In those early years Afrikaans literature was limited and the linguistic description of Afrikaans still in a preliminary stage.

In 1929, the University of Stellenbosch took the responsibility for the dictionary from Nasionale Pers. Shortly thereafter the dictionary office moved to Stellenbosch, and in 1937 a dictionary committee was appointed as a controlling body.

In 1945, Prof. Smith retired due to ill health and the dictionary committee was replaced by a board of control consisting of representatives from the government, the University of Stellenbosch and the Suid-Afrikaanse Akademie vir Wetenskap en Kuns. When Prof. Smith retired after nineteen years of lexicographic labour, not a single volume had been published. However, manuscripts ranging from a preliminary to a revised state had been prepared, in the style of a standard dictionary, up to the letter $\mathrm{N}$.

There are reasons why nothing was published in nineteen years. By 1926, the Afrikaans language was not yet standardised. No extensive recording of the Afrikaans language had been undertaken and there was only a very limited corpus of literature which could be excerpted. No comprehensive study of the Afrikaans grammar had been undertaken, many spelling issues still had to be resolved, and furthermore there was an almost complete lack of technical terms.

Two other impeding factors were the absence of etymological research and contradicting opinions on the inclusion of Dutch words. Some critics were convinced that the database of Prof. Smith was too Dutch-oriented, whilst others propagated the inclusion of more Dutch words.

In October 1946, Dr P.C. Schoonees was appointed as second editor-inchief. When the first volume of the WAT was published four years later in 1950, it was not a dictionary in the tradition of a Van Dale or a Shorter Oxford as it had always been expected. It had the character of a comprehensive descriptive dictionary and was on the whole well received by academics, writers and users.

It can therefore be argued that 1950 marked the real beginning of the WAT. In 1951, the editorial staff was enlarged to ten members.

To compensate for the lack of Afrikaans technical terms, many Dutch terms were included in the first volume of the WAT. Following the advice of leading linguists, other Dutch words were also included on the grounds that they could be necessary for Afrikaans in the future, even though they were not 
part of the Afrikaans vocabulary at the time of compilation. None of these words really became part of the Afrikaans lexicon, as Afrikaans and Dutch continued to move further apart from each other. No etymologies were given, but the language of origin was provided in the case of loan-words. Thus, by the time the first volume of the overall descriptive WAT appeared in 1950, no standard descriptive dictionary had been published. By 1950, Afrikaans had a well-established written literature and compilers of dictionaries could benefit from a greatly but not completely standardised language. Volumes II, III and IV were respectively published in 1955, 1958 and 1961, and were all enthusiastically received.

In 1962, Dr F.J. Snijman was appointed as the third editor-in-chief and in 1963, the first millionth language data record was received by the WAT. Unfortunately, the publication of volume V in 1968, of volume VI in 1976 and of volume VII in 1984 was marked by strong criticism aimed mainly at the slow alphabetic progress, the encyclopaedic treatment of lemmas and the strong accent on technical terms.

In 1970, the second millionth record was received and in 1973, the Woordeboek van die Afrikaanse Taal Act, Act No. 50 was passed. The dictionary was established at Stellenbosch on a permanent basis, although not as part of the University of Stellenbosch. Henceforth the Bureau of the WAT was under a board of control consisting of five members in which the State, the University of Stellenbosch and the Suid-Afrikaanse Akademie vir Wetenskap and Kuns were represented.

In 1981, Mr D.C. Hauptfleisch was appointed as fourth editor-in-chief and in 1983 the collection of lexical material reached the three million mark, owing to the enthusiastic collaboration of language users across the country. This collection of lexical material is an ongoing process.

The Woordeboek van die Afrikaanse Taal Amendment Act, Act No. 9 was passed in 1986. The board of control was enlarged to six members. The administrator, in future also the permanent chairman, and the editor-in-chief, are $e x$ officio members and four members are appointed by the Minister of National Education. One member represents the Suid-Afrikaanse Akademie vir Wetenskap en Kuns.

The fact that the compilation of the three and a half volumes of the letter $\mathrm{K}$ took almost thirty years gave rise to predictions that it would take more than two hundred years to complete the WAT, which would then to a large extent not be a true reflection of the Afrikaans language any more. Therefore, in 1987 the Bureau started with its computerisation program in order to accelerate the editorial process and in 1989 a process of strategic planning was implemented with a view to completing the dictionary up to the letter $Z$ as quickly and effectively as possible.

The achievements of the WAT are all the more remarkable when one bears in mind that almost every possible mistake, especially as far as management 
and planning are concerned, was made. Hopefully future lexicographers would learn from the WAT's experience and would not be prone to the same mistakes.

\section{The current situation}

By 1989 it was clear that in spite of some measures implemented to accelerate the work on the WAT, the editors were not reaching their goals fast enough.

What really changed the situation was the strategic planning undertaken in 1989. It was done under the guidance of Dr D.J. van Schalkwyk, who was then senior coeditor and who became editor-in-chief in 1991. At the same time, the computerisation of activities was increased to its fullest extent and with the help of metalexicographers an optimally user-friendly dictionary was being pursued.

The entire editorial staff was involved in the strategic planning and by the completion of the process after six months, in November 1989, a mission was defined, aims and goals were formulated, action plans were worked out and target dates were set. Ten focus areas of the Bureau were identified, namely:

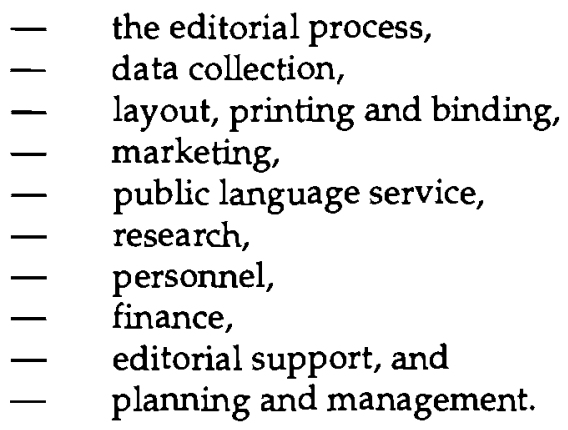

Thereafter the replanning of the design of the dictionary was started, which was done in close co-operation with nine leading South African linguists. They were all involved in lexicographic projects and most of them also lectured in lexicography. A new editorial manual or style guide was developed, incorporating as many of the suggestions of the metalexicographers as was practically possible.

The principal aim of the strategic planning was to speed up the work on the dictionary drastically and this was realised when volumes IX and $X$ were each completed within a period of two and half years. The completion of the two preceding volumes each took an average of seven years. This increased output was made possible by several positive outcomes of the strategic planning, such as good management, the development of production norms, a strict adherence to target dates, computerisation, and the development of a new manual or style guide. 
The database also benefited from computerisation as the electronic corpus is now far bigger than the card collection. The staff also have access to e-mail and the Internet and the Bureau of the WAT has a website.

Inspired by one of the aims in the mission, i.e. to act as a growth point and stimulus for lexicographic activities and metalexicographic reflection and to liaise with South African and foreign lexicographic institutions, it was decided to publish a series of journals and books under the banner of AFRILEX.

In 1991, Lexikos, a lexicographic journal, became the first publication in the AFRILEX series. As the only professional journal in Africa devoted exclusively to lexicography, it has since then appeared annually.

One of the principal aims of the AFRILEX series was to promote the establishment of a lexicographic society for Africa. This stemmed from the Bureau's awareness of the expertise present in other lexicographic projects in South Africa, which led to its investigation of the idea of co-operative lexicography. In July 1995, the African Association for Lexicography, AFRILEX was established and in 1996, Lexikos became its official mouthpiece. Lexikos is however still compiled and published by the Bureau.

One of the most important reasons for the acceleration of the work on the dictionary was the development of production norms for all staff members. Once production norms had been introduced, the Bureau developed an inservice training course which aimed at developing the lexicographic skills of new staff members as rapidly as possible.

As the idea of co-operative lexicography gained momentum at the Bureau, a training course for lexicographers and people interested in lexicography from outside the Bureau was developed in 1995. This course in general and computer lexicography and in the planning and management of lexicographic projects stretches over two weeks and is usually offered twice a year. Since 1995, students, lecturers, practising lexicographers and persons intending to become involved in dictionary compilation have attended the course. Participants have come from almost all the provinces of the Republic of South Africa and from as far as Angola, Namibia, Gabon, Tanzania and Zambia.

In 1997, two of the staff members of the Bureau also offered the course at the Centre International des Civilisations Bantu (CICIBA) in Libreville, Gabon, where six African countries were represented.

The Bureau wholeheartedly supports the initiatives of other dictionary projects, such as the Dictionary Unit for South African English and the Sepedi Dictionary Project, to offer training programmes.

At the end of every year, the Bureau formulates strategic aims for the next year in order to ensure that the staff works purposefully. The editor-in-chief draws up a goal-orientated budget in accordance with these strategic aims, which assists goal-orientated management. To contribute to lexicographic theory and practice, staff members annually produce scientific publications and deliver papers at national and international congresses.

True to its mission, the Bureau started producing satellite dictionary publications in co-operation with external authors in 1992. Such publications 
appeared in 1992, 1994 and 1995, and included a dictionary of idioms and a mini thesaurus. An etymological dictionary is currently being compiled in cooperation with both international and national external authors. The typesetting of these publications as well as that of the WAT itself is done by the Bureau.

The Bureau has undergone a transformation over the past ten years, resulting in an organisation managed according to modern principles, in the acceleration of work on the dictionary and in a redesigned dictionary which reflects state of the art linguistics as far as is practically possible. A desire to cooperate with other projects, to learn from their experience and expertise and to share its own expertise, especially in the fields of joint publications, training, computerisation and the planning and management of a lexicographic project has also developed.

\title{
Dictionary Unit for isiNdebele
}

\author{
P.B. Skhosana, Department of African Languages, University of Pretoria, \\ Pretoria, Republic of South Africa
}

\section{Introduction}

At the conference Lexicography as a Financial Asset in a Multilingual South Africa held in 1996 at the Bureau of the Woordeboek van die Afrikaanse Taal in Stellenbosch, it was indicated that isiNdebele lexicography was still nonexistent. At that time, most of the necessary basic work had not yet been done, for instance:

- printed and published literary material in isiNdebele for corpus building was insufficient,

- consultation with all the relevant stakeholders of isiNdebele had not yet taken place, and

isiNdebele itself was not yet a university subject like the other official languages of South Africa.

However, the conference acted as an eye-opener. The establishment of a dictionary unit for isiNdebele was mentioned as an urgent need, since not a single isiNdebele dictionary existed. This need still exists, even though some remarkable progress had been made towards establishing an official Dictionary Unit for isiNdebele.

\section{Mission statement}

It is the aim and the objective of the Dictionary Unit for isiNdebele to produce a comprehensive monolingual dictionary that will benefit the mother-tongue 
speakers of isiNdebele and also all other South Africans who are interested in studying the language within a short period. The product should benefit scholars, students and professionals. As dictionary making is not an easy short-term process, the Dictionary Unit for isiNdebele does not intend to complete the letters of the alphabet consecutively, but to work on a complete dictionary, increasing the scope and volume as the project continues. This seems to be the best strategy to short-circuit the lengthy period dictionary users will have to wait before the first isiNdebele dictionary becomes available. A bilingual dictionary that will be of benefit to the non-mother-tongue speakers of isiNdebele is also considered.

\section{History and mandate}

The establishment of officially funded dictionary units for all the African languages of South Africa demands proper planning and a joint venture in order to make these units successful. That is the reason why the Dictionary Unit for isiNdebele went through a number of important stages in the past two years in order to qualify for recognition and official funding. An open and successful consultative conference was held in Mpumalanga at Loopspruit Wine Cellars on 14 March 1997. The main aim of this conference was to ascertain whether there is any support from grass roots level for the establishment of the dictionary unit for isiNdebele and to assure that the unit functions in close co-operation with all the stakeholders involved in the development of isiNdebele. More than 50 delegates representing major role players, individuals, interested parties and institutions such as the South African Bible Society, AFRILEX, National and Provincial Departments of Arts, Culture, Science and Technology, universities, writers' associations, specific language bodies, tribal institutions etc. attended the conference. Overwhelming support for the following issues was received:

- that as a starting point a monolingual type of a dictionary be the first priority,

- that the initiative of the Department of Arts, Culture, Science and Technology of Mpumalanga to find a possible and suitable institution or venue that can host this unit, is highly appreciated,

- that the University of Pretoria, the nearest tertiary institution to the speakers of isiNdebele and the only university willing to introduce this language as a university course in 1997, be officially approached to host this unit,

that official correspondence also be extended to PANSALB for recognition and support, and

- that in order to ensure that the unit starts functioning successfully and progresses well, Mr P.B. Skhosana be nominated as the person responsible. 


\section{Corpus collection and building}

While waiting for the government to come up with official directives and guidelines on the composition and size of the management, personnel and other official administrative procedures for funding, the Unit started with the corpus collection. It managed to compile a reasonably extensive data corpus from written sources of isiNdebele literary works as well as oral material recorded from native speakers of isiNdebele. In addition to this, it has already started with the electronic scanning of isiNdebele literary works for the purpose of compiling a head-word list as well as for word-frequency studies. Through the support of the stakeholders and academic staff of the University of Pretoria, among others Prof. D.J. Prinsloo and Prof. A. Wilkes, about 20000 entries have been collected so far.

The intensive two-weeks-long workshop, the SALEX '97 Lexicographical Training Course, which was held in Grahamstown from 15-27 September 1997 was attended by the Dictionary Unit for isiNdebele as part of its ongoing training programme.

\section{Conclusion}

The Dictionary Unit for isiNdebele is still in its infancy. Training and close contact with those experienced in the dictionary-making processes are prioritized. The Dictionary Unit of isiNdebele will therefore not adopt a policy of working in isolation but will profit from the excellent expertise available from already well-established projects.

\section{Dictionary Unit for South African English}

Penny Silva, Former Executive Director, Dictionary Unit for South African English, Rhodes University, Grahamstown, Republic of South Africa

\section{The main objects and the mission statement of the Dictionary Unit}

The original mission statement reads as follows:

The continuous and comprehensive collecting, arranging and storing in a lexicographically workable form of the vocabulary of the English language as used in Southern Africa and the editing and publication of the collected materials in the form of a Dictionary of South African English on Historical Principles, as well as periodical revision and updating of the text thereof and other research and publications associated therewith. (Memorandum of Association, 1991) 
When the monolingual dictionary had been published, it was realised that the object had to be extended and the Registrar of Companies had therefore to be approached to accept a change in the mission statement.

With the addition of 1 (b) and (c) and 2, the total mission statement now reads as follows:

1. The continuous and comprehensive collecting, arranging, and storing in a lexicographically workable form of the vocabulary of the English language as used in Southern Africa and the editing, adaptation, and publication of the collected data in printed and electronic form -

(a) as a Dictionary of South African English on Historical Principles,

(b) as similar dictionaries, and

(c) as a component of English or bilingual dictionaries (in collaboration with other agencies),

as well as periodical revision and updating of these texts, and other research and publications associated therewith.

2. The preparation and provision of short courses in lexicographical theory and methodology.

All these aims are realised simultaneously. But the main aim is the documentation of English in South Africa, how it is used, how it is affected by other languages, the differences in English in South Africa from English everywhere else. English changes rapidly, being a language which not only develops new meanings within its own vocabulary stock, but also borrows from other languages with which it comes into contact.

To add to the main object of the Dictionary Unit, there is a general statement of ideals which is the following:

The Dictionary Unit for South African English affirms the value and dignity of all South Africa's languages and the need for their development and documentation. The Unit recognises and values the contribution made by all the country's languages to the development of South African English and is committed to reflecting the rich heritage of our multilingual society. It believes that developing a pride in South Africa's languages is a powerful component of nation building.

Considering the central role of English as a language of communication between South Africans and with the wider world, the Unit is committed to the recording of the history and culture of English in South Africa and the study of its changing vocabulary. The Unit is also committed to producing dictionaries which will enable better access to English by all of the country's communities, and also to sharing expertise through teaching, training and consultation.

In order to contribute to the world-wide study of English and to ensure that South African English maintains and develops its place as a 
member of the family of world Englishes, the Unit undertakes to share its knowledge of South African English with the international community of lexicographers.

\section{The early history of the Unit}

\subsection{Establishment and consolidation}

The first dictionary of South African English, Africanderisms, was published in 1913, compiled by an amateur lexicographer - a Methodist minister, the Revd Charles Pettman. Emulating the Oxford English Dictionary, Pettman's dictionary illustrated usage by including quotations from printed works.

The next South African dictionary appeared only in 1975 - A Dictionary of English Usage in South Africa, compiled by Ridley Beeton and Helen Dorner, of the University of South Africa, Pretoria.

In mid-1968, William Branford, then professor of English Language at Rhodes University, Grahamstown, seeing the need for ongoing research on South African English, initiated a pilot project, employing Peter Kota as parttime editorial assistant during 1969. The Dictionary Unit for South African English was established as a project of the Institute for the Study of English in Africa, at Rhodes University. The Unit aimed to investigate the extent to which South African English was distinctive from other Englishes, and whether documenting it would be feasible.

In 1970 Betty McLeod was appointed as the first full-time professional researcher, and subsequently Penny Silva joined the Unit in August of that year. Under Professor Branford's supervision she was assisted by Doreen Gray in collecting quotations from books, manuscripts, magazines, and newspapers and mounting them on index cards in order to illustrate English usage in South Africa. Rare early printed and manuscript material was read in the University library, and contemporary material was gleaned from a competition run in a national magazine, as well as from wide reading of modern publications. Mrs Silva began drafting entries in 1971. Jean Branford joined the staff during that year, followed by Margaret Britz, and, in 1974, by John Walker. Work was overseen by an editorial committee chaired by Professor Branford and drawn from the academic community. By the end of 1973, a working system had evolved, a style had been designed, and the first thousand entries had been written for the planned Dictionary of South African English on Historical Principles.

\subsection{Financial support}

In May 1969 Professor Branford wrote to the Human Sciences Research Council (HSRC), asking for support for a permanent unit. In December of that year the 
Council granted the sum of R19 000, which enabled the project to continue its work until 1973. The HSRC referred the matter to the Department of National Education, with a strong recommendation that a permanent institution be established "along the lines of the office of the Afrikaanse Woordeboek, at the University of Stellenbosch".

However, a sixteen-year-long struggle for the establishment of a permanent unit followed. Throughout this period the Department of National Education supported the Unit with ad hoc annual grants, which made effective planning and the appointment of staff on a long-term basis almost impossible.

For the period April 1975 until March 1981, the Unit received a single grant of R90 000 from the Department of National Education. As this amount did not cover costs, each year the considerable shortfall was met by a grant from the University Council. A further subvention was given for the period 1981 to 1984 . In 1985 the Department of National Education finally agreed to make the project permanent, and a more realistic annual grant was allocated.

Since 1994, the Unit has been supported by the Department of Arts, Culture, Science and Technology. Tribute should be paid to Professor Branford's foresight in initiating research into the South African English vocabulary, and to his perseverance in obtaining money, year by year, to support this work. The Unit has filled a gap in international lexicography for English, and has documented both the creativity of local English and the effects on it of the other South African languages. The Unit has also established South African English lexicography as a scholarly discipline, nationally and internationally.

\subsection{Staff}

The staff of the Dictionary Unit has usually been small: for instance, in 1970 there was one full-time researcher with a part-time typist; in 1976, one parttime researcher, an editorial assistant, and a part-time typist; and in 1988 one senior and three junior full-time researchers, one part-time researcher, and a part-time typist.

Because there had been some savings made over the years, in 1990 the staff complement was expanded in order to prepare for the editing of the large Dictionary of South African English on Historical Principles over the following five years. From 1991 to 1995 there were five editors, one part-time editor and a keyboarder, with temporary assistance from students. In 1996 and 1997 there were five editors, one part-time editor and a part-time keyboarder. During 1998 the staff consisted of three editors, two part-time editors and a part-time keyboarder.

While over the years many worked in the Unit for very short periods of time, two editors ensured continuity, making a major contribution: Jean Branford from 1971 to 1989, and Margaret Britz from 1971 to 1991. 


\section{$2.4 \quad$ Legal status}

The Unit's precarious position changed in June 1991 when it was established as a permanent national body. After lengthy negotiations between the Department of National Education and the University, the Dictionary Unit for South African English was established as a Section 21 non-profit company with a nationally representative board of directors. It is associated with Rhodes University as a research institute and has been an associated institution of the Department of Arts, Culture, Science and Technology since 1994.

\subsection{Publications associated with the Unit}

The first small sample of work in progress - fifty entries - was published in 1971 as a report to the Department of National Education. In 1976, interim unpublished text of between one and two thousand entries was produced, again for the sponsors of the project. It was titled Voorloper ("one who walks ahead"). Agterryer ("one who rides behind") followed in 1984, as a further report to the Department.

In 1978, Jean Branford's Dictionary of South African English was published by Oxford University Press as a short dictionary for general readers, and four editions have appeared, the most recent in 1991. William Branford edited the South African Pocket Oxford Dictionary, published in 1987 with a second edition in 1994.

During the preparation of the Dictionary of South African English on Historical Principles, email was invaluable, as it provided almost immediate access to expert consultants in many fields, and particularly to the historical lexicographers of the Oxford English Dictionary in Oxford. The South African editors were not only able to ask questions and exchange data, but also to undergo an informal, long-distance training in historical lexicography, owing to the generosity of their Oxford colleagues. This reshaped the style and scholarship of the dictionary considerably as the editing progressed over the five-year period.

The dictionary was published in August 1996. The delivery of the text to the publishers appears to have been a world first: the huge and complex electronic text was transmitted to Oxford entirely on the Internet, with a stop in the United States in order to have tagging added. The dictionary is online in the Dictionary Department in Oxford, enabling lexicographers to have access to information on South African English as they add new words to world dictionaries including the Oxford English Dictionary, the New Oxford Dictionary of English, and the Concise Oxford Dictionary.

After the dictionary had been completed the Unit began to look in new directions, and in 1995 work was begun on the Francolin Illustrated School Dictionary for Southern Africa, a learner's dictionary for the higher primary school, compiled mainly for rural and township children. The editors were Dorothea Mantzel and Bernd Schulz, and the text was compiled with assistance 
from two non-governmental organisations working in literacy, the Molteno Project and the Read Educational Trust. The book covers a vocabulary of 3414 words (including core South African words and 800 curriculum terms), uses simple language, and provides illustrative sentences and many line drawings. It was tested in forty-six rural schools in six provinces before publication in July 1997.

\subsection{Training and teaching}

In 1997 the Unit became involved in the practical training of lexicographers. The British Council assisted by bringing three experienced British lexicographers and trainers to run the course, under the leadership of Sue Atkins. SALEX ' 97 was organized by the Unit under the auspices of AFRILEX and the Department of Arts, Culture, Science and Technology, and took place in Grahamstown in September 1997. It was the first course of three planned by AFRILEX with the central goal of enabling the staffs of new units for the nine African languages.

The ten-day course was attended by thirty-five participants representing fifteen languages - ten of the eleven South African official languages, and several languages from beyond South African borders. Each working day consisted of two lectures and two related workshop sessions, and every participant went away with a large file containing the course material for later use. Response to the course was positive, and a heartening spirit of common purpose developed among those present.

The Unit has established contact with schools, in Grahamstown and in the Eastern Cape. A pilot website has been set up at a local primary school, enabling the children to send words to the Unit - particularly school slang which they think might be useful in the documentation of South African English. One of the editors has visited the school, talking to both pupils and teachers. It is hoped to extend the project to other schools. Contact was made with the provincial Department of Education, offering the Unit's resources.

The Unit has also participated in Grahamstown Foundation projects, lecturing teachers on dictionary use, speaking at the National Festival of the Arts, and at national and provincial schools' festivals, and preparing material for the English Olympiad (an essay competition for high school pupils).

\section{$2.7 \quad$ Resources}

Money has always been tight, and in the future the situation is unlikely to improve. About $86 \%$ of the funding is spent on staff salaries. The Unit does not have the funds needed to send staff to conferences, to provide training, even to buy reference books for its small library.

The Unit benefits greatly from the University's resources, including services such as the management of its finances, administration of the payroll, and 
membership of the University's pension, medical aid, and group life schemes. The University also provides access to email and to computing expertise, as well as assistance with marketing and personnel matters. The Unit rents accommodation from the University at a subsidized rate, and benefits from using the University's messenger services, cleaners, and maintenance staff. The University library and the specialisms of the academic staff are invaluable resources. The Unit pays the University $5 \%$ of its annual income for these services.

\section{The Unit's place in changing society}

Since the large dictionary was completed, tasks have become much more diverse and the staff háve had to learn a range of new skills. Two major factors affect the way in which the Unit sees its future. The national position of English began to change in 1990 when it became the language of negotiation between the National Party government and the African National Congress (ANC). Despite being just one of the eleven official languages, English has become a language of communication at central government level and in many regions. There is a growing need for a range of access to English dictionaries, suited to the diverse community.

The Unit is about to turn its attention to South Africanising British dictionaries, for both first- and second-language speakers of English, adding South African vocabulary and special senses. There will also be a growing need to work with the units for all the other South African languages, especially perhaps in the preparation of bilingual dictionaries, where the Unit could manage a "framework" for English, and provide this as a resource for the creation of the other side of the bilingual dictionary.

Then there is the increasingly sophisticated technology available to the lexicographer. With diminishing resources for staff, and increasing demands being made, it is vital to hamess this technology. The Internet, email, scanning, electronic corpus-searching, CD-ROM, SGML-tagged text, networked workstations - all of these resources are already in use in the Unit, but need to be refined and extended. All computers have recently been upgraded to the same capacity, so that these resouces can be accessed by all staff.

One of the Unit's editors, Madeleine Wright, is designing lexicographical editing software, configuring SGML to suit the Unit's needs within a commercial word-processing package, and investigating commercial search engines. The huge task of capturing the Unit's thousands of index cards electronically is still to be accomplished.

At the same time the Unit continues to update the large dictionary and to collect data for it: but the window period between contracts is also used to evaluate and reorganise the various systems in place in the Unit, so that it is ready to meet the new demands of the years ahead, under the leadership of its new director, Katharine Kavanagh. 


\section{Sepedi Dictionary Project}

D.J. Prinsloo, Department of African Languages, University of Pretoria, Pretoria, and K.J. Mashamaite, Department of Northern Sotho, University of the North, Sovenga, Republic of South Africa

\section{Mission}

The mission of the Sepedi Dictionary Unit is to compile a monolingual explanatory dictionary. Since the need for dictionaries is so great, it will suit the interests of all prospective users to publish spin-offs from the project on a regular basis while completing the final project.

\section{History}

In 1988, the Department of African Languages at the University of Pretoria was formally appointed or instructed to establish a dictionary project for Sepedi with the final goal to compile a comprehensive multi-volume monolingual dictionary for Sepedi, with the now discontinued Sepedi Language Board as the controlling body. This was to be a major dictionary project similar to the Woordeboek van die Afrikaanse Taal. A well-motivated request for funding of approximately $\mathrm{R} 1$ million per year was well received by the authorities but no money was granted.

When the University of Pretoria was subsequently approached, it allocated an amount of more or less R8 000 per year. In addition, the University also provided the comprehensive infrastructure in the form of an office, telephone, fax and up-to-date computer technology and free services of computer programmers. The annual cash allocation of R8 000 is too small to hire a single full-time lexicographer, but it is utilised in the most effective way to maintain the project.

A Dictionary Committee was formed and supplemented from time to time, namely P.S. Groenewald, J. Maripane, K.J. Mashamaite, M.J. Mojalefa, D.J. Prinsloo and B.P. Sathekge. These members work on the dictionary in their spare time. Not a single member could be released from his duties as lecturer to attend to the dictionary on a full-time basis. This situation has slowed down the process considerably and is still far from what was initially hoped to be achieved in terms of full-time dictionary compilers. Nevertheless, much progress has been made since 1988. A word-frequency study based on a 1,5 million word corpus has been completed.

As for the dictionary itself, almost 50000 entries have been computerised. Two pocket-size bilingual dictionaries based on the research done and experience gained are already on the market. A comprehensive single volume English-Sepedi, Sepedi-English dictionary is scheduled to be on the market within 
the next three years. However, these remain spare-time efforts. At the moment the team is assisted by Mr G.-M. de Schryver from the University of Ghent in Belgium.

In 1996, co-operation with the University of the North was established, the University being represented by $\mathrm{Mr} \mathrm{K}$.J. Mashamaite.

In 1997, a formal business plan for the establishment of a dictionary unit was presented to the Department of Arts, Culture, Science and Technology.

The Sepedi Project held a consultative meeting on 13 August 1999 at the University of the North. The aim of this meeting was to bring all role-players together to:

- discuss the dictionary needs of Sepedi,

- communicate the latest legislation regarding dictionary units,

- obtain expert advice on the compilation of monolingual dictionaries,

- extend the mandate of the Sepedi Project Committee to compile a monolingual dictionary,

- appoint more members to the Sepedi Project Committee, and

- mandate the new committee to draw up a business plan according to the requirements of PANSALB.

The Dean of the Faculty of Arts, Mr S. Mashegoane, officially opened the meeting. The coordinators of the Sepedi Project, Prof. D.J. Prinsloo and Mr K.J. Mashamaite respectively read papers on the "Sepedi Dictionary Project: Past to Present" and the "Sepedi Dictionary Project: Present to Future". Ms Eleanor van Zuydam, Deputy Director: Language Development (National Lexicography Units), addressed the meeting on "Norms and Regulations for the Establishment of a National Lexicography Unit for Sepedi". This was followed by a presentation entitled "Compilation of a Monolingual Dictionary for Sepedi" by Prof. R.H. Gouws. Finally an in-depth discussion by role-players was held and it was decided to increase the Project Committee with five more members. The meeting accepted the offer by the University of Pretoria that the University of the North will become the new head office of the Sepedi Project, with the University of Pretoria acting as its branch office. A set of monolingual English dictionaries was donated to the Sepedi Project by the Dictionary Unit for South African English.

Much lexicographical research has evolved around the Dictionary Project. For example, a course work M.A. was introduced at the University of Pretoria five years ago and approximately fifteen students enrol annually for either magister or doctoral studies in African Language Lexicography. In-depth research into the problematic aspects of lemmatisation in Sepedi, as well as word-frequency studies have been done. The Project developed sophisticated word-frequency and concordance computer programmes and in co-operation with AFRILEX, has taken the initiative to compile a computer program for the compilation of dictionaries which might be useful to other projects as well. 
The Sepedi Dictionary Project is doing fine under the circumstances. A lot of work and research has already been done. A lot of lexicographical problems have been solved. The University of Pretoria is prepared to continue with its support on all levels. The Sepedi Project already has a lot to offer to other dictionary projects for African languages in terms of research done, training offered, computer programs developed, etc.

\section{The future}

The history of lexicography and lexicographic research in African languages is marked and dominated by research output from non-mother-tongue speakers of the languages. Common examples can be found in the numerous dictionaries in each African language today. All compilers are non-mother-tongue speakers and in some cases mother-tongue speakers are co-compilers. These mother-tongue co-compilers did not have any knowledge of the principles of lexicography and of metalexicography in particular.

Non-mother-tongue speakers fulfilled an important function in the development of the African languages. But it is important that the mother-tongue speakers now double their efforts and commitment to make it their task and obligation to write and compile dictionaries in their respective languages.

Institutions of higher learning such as universities and technikons, especially at the historically black universities, should take the initiative to accommodate lexicography units and start offering courses in lexicography, because this is an urgent need.

The University of the North has demonstrated this in two ways. Firstly, in 1994, two staff members were sent to the Free University of Amsterdam in the Netherlands to follow a professional Masters programme in lexicography. Secondly, lexicography as a course has been introduced at undergraduate and postgraduate level at the University of the North.

At the University of the North co-operative lexicography is encouraged. The University and the University of Pretoria have reached an important partnership in Sepedi dictionary projects. The needs of the community are far more important than those of the individual institutions. Although the ultimate goal is to complete a comprehensive monolingual dictionary of Sepedi, the compilation of a standard monolingual dictionary of Sepedi and other bilingual learner's dictionaries should also be considered.

For these projects to yield comprehensive and representative products that are reliable and that would meet the needs of the users, an extensive Sepedi vocabulary gleaned from various fields such as commerce and industry, government, religion, law, etc., has to be built into the Sepedi database. This exercise will need adequate funds to employ and train research assistants to gather oral information as well as data from the printed media. 


\section{Xhosa Dictionary Project}

T.X. Mfaxa, Editor, Xhosa Dictionary Project, University of Fort Hare, Alice, Republic of South Africa

\section{The mission and aims of the project}

The Xhosa Dictionary Project's mission is to serve the interests of the isiXhosaspeaking community in accordance with the basic human rights of this community, and fulfilling its members' needs by recording, using, developing and advancing the use of the language in oral, written and electronic form and in its multilingual interaction with all other language groups, both locally and abroad.

The aims are summarised as follows:

The primary aims are -

- to compile a national corpus of the isiXhosa language and to produce a comprehensive explanatory dictionary of isiXhosa;

- to provide a research facility for the study of the language in general and lexicology and lexicography in particular;

- to provide isiXhosa language services and support services, including translation services, terminology services, abridged dictionaries and specialised dictionaries, and reference services for researchers and language users;

- to promote and improve co-operative lexicography by means of experience gained over the years; and

- to complete the remaining volumes of the Greater Dictionary of Xhosa.

Secondary aims are -

- to establish a national lexicographic centre for African languages to advance the concept of multilingualism and promote the use of previously marginalised languages like isiXhosa;

- to monitor, report and advise on the viability of isiXhosa as a medium of communication at all levels in society, both within its mother-tongue community and beyond; and

- to play a significant role in the marketing and ultimately sales of both the larger and the smaller dictionaries in a cost-effective manner. 


\subsection{Historical overview}

The Eastern Cape, in particular the Victoria East subregion, is the cradle of all growth and development in relation to isiXhosa. It was here that the language was first committed to writing. It was also here that the first printing press in South Africa was acquired specifically for the printing of works in isiXhosa. And it was here that the first authors of isiXhosa literature were concentrated and it was also here that the first attempts at compiling isiXhosa dictionaries were made.

The Xhosa Dictionary Project was started in 1968 as a project of the University of Fort Hare under the late Prof. H.W. Pahl as its director and editor-inchief. It was in response to the needs of students of the isiXhosa language for a modern, definitive, scientific standard dictionary. The dictionary entitled the Greater Dictionary of Xhosa is a comprehensive trilingual dictionary. Its headwords are entered and defined in isiXhosa and then translated into English and Afrikaans. It also has fifty-two addenda containing information on grammatical, historical, anthropological and cultural aspects of isiXhosa.

It is divided into three volumes, namely Volume I with words belonging to letters $\mathrm{A}$ to J, Volume II with words under $\mathrm{K}$ to $\mathrm{P}$ and lastly Volume III with words starting from $Q$ to Z. In 1989 Volume III was published. The reason for starting with this volume was due to the fact that the sponsors were anxious to see some tangible results of their contributions. Therefore the then editors decided to publish the third volume, whose contents was more organised and ready for publication than that of the first two volumes. The two other volumes are still in preparation.

This project is the largest and most established lexicographic project not only for isiXhosa, but also amongst the other African languages of South Africa. It caters for the needs of both academic and ordinary language and dictionary users. Also of importance is the project's experience in compiling the largest most inclusive dictionary in an African language in South Africa. As a result of this, the project can serve as a ready model for the establishment of new lexicography projects or the growth of already established projects in other African languages.

\subsection{Funding}

While the University of Fort Hare assumed the major financial responsibility from its inception, the project was as well supported by the Human Sciences Research Council of the Republic of South Africa, the governments of the former Republics of Ciskei and Transkei, and the Anglo-American and De Beers Chairman's Fund. It also received a generous publication grant from the then Department of Education and Development Aid of the Republic of South Africa. 


\subsection{Data gathering and editorial process}

Data was collected through field research and by the perusal of written material. It must however be mentioned that $A$ Kafir-English Dictionary (1915), written by $\mathrm{A}$. Kropf and R. Godfrey and also Godfrey's unpublished manuscript, which was an attempt to revise $A$ Kafir-English Dictionary, were also major sources of entries. This data was then recorded on cards and an alphabetic arrangement of entries was done manually. Each entry occurred on a short card, in ordinary paragraph form and also on a long card, in which the three languages, isiXhosa, English and Afrikaans, were arranged in this order.

The use of a computer was first introduced in the project at the beginning of 1989 when the director and editor-in-chief Prof. B.M. Mini came into office. During this time the first computer typist started typing entries on the computer from the long cards, using the word-processing program called XyWrite III Plus, version 3,54. However, the card system delayed the progress and consequently the publication of the rest of the dictionary.

\section{The present situation}

\subsection{The functions}

To achieve the already stated aims, the project is performing the following functions:

- It is collecting, processing, recording and storing vocabulary items of isiXhosa and its various dialects.

- It acquires by various means, including translation, accurate English and Afrikaans equivalents for the isiXhosa items.

- It does lexicographic editorial work on the collected data.

- It collects, stores and records in addendum form, anthropological and cultural information relating to some of the entries of the dictionary.

- It offers translation services for the local community, both provincially and nationally.

\subsection{Compiling and editing}

All the editors have personal computers and are computer literate. Entries are no longer recorded on cards. To accelerate the editorial process, the card-based database is being converted to an electronic database. Many of the problems peculiar to isiXhosa lexicography have already been solved. Complications caused by the trilingual format of the dictionary have also been addressed. 


\subsection{Management of the Project}

Two committees serve as facilitators for the affairs of the project. These are the Xhosa Dictionary Advisory Committee and the Xhosa Dictionary Executive Committee. The membership of the Xhosa Dictionary Advisory Committee has a representative from each of the sponsoring organisations and bodies, one each from the University of South Africa, the University of Cape Town and Rhodes University, and the manager of the Lovedale Press who represents the Church of Scotland. Internal members are the director and editor-in-chief of the project, the Rector of the University of Fort Hare, the head of the African Languages Department of the University of Fort Hare and the Council representative also from the Department of African Languages. The Xhosa Dictionary Executive Committee consists of all the internal members of the latter committee, as well and the Lovedale Press representative.

\subsection{Staffing}

The project has five full-time editorial staff members, and one temporary administrative secretary.

The editorial staff consist of the director and editor-in-chief, two editors and one assistant editor for isiXhosa, and an assistant editor for Afrikaans.

\subsection{Present funding}

The furiding of the project has until now been the responsibility of the University of Fort Hare. The University is entitled to make all or part of its contribution to the funding of the project by the establishment and maintenance of posts within the project and by the provision of office space and other necessary services for the project.

All funds raised by the project or donated to the project are kept in an account within the financial administrative system of the University of Fort Hare. Such funds are managed in terms of the University of Fort Hare's financial accounting procedures. The University of Fort Hare auditors usually audit the accounts annually.

\subsection{Accommodation}

The Xhosa Dictionary Project is situated on the campus of the University of Fort Hare, with eight offices, including a strongroom. The office space can easily be extended to accommodate more staff, should the need arise. The strongroom stores the project's archival material, namely the short and long cards arranged alphabetically, computers and other valuables. 


\subsection{Computer Support Services}

The project has sufficient hardware for its present needs. However, an uninterruptible power supply, and a flatbed scanner and tape-streamer back-up system would be welcome additions.

As far as software is concerned, the project is in the process of converting from a word processor to a database. A number of database options are being evaluated. All the members of staff of the project are on e-mail. It is therefore easy for lexicographers from other units to make contact with the members of the Xhosa Dictionary Project.

\subsection{Relations with outside organisations}

Since the Greater Dictionary of Xhosa is trilingual, it contributes to the realisation of multilingualism.

Channels of communication and co-operation between the project and a large section of the South African community, as well as other lexicographic centres in South Africa, are already open.

Members of the staff of the project are affiliated to and are regular participants of the following professional organisations: the American Association for Lexicography, the African Languages Association of Southem Africa, the South African Folklore Society and the South American Translators Institute.

\subsection{Lexicographic Research and Training}

The interest in the production of dictionaries in South Africa presented an opportunity for this project, with its experienced staff and large collection of processed data, to develop courses in lexicography, incorporating the metatheory of compiling dictionaries in the African languages.

At present, staff members are involved in the study of the phonetics of isiXhosa, in the writing of a specialised Xhosa Bible Dictionary and in management studies. As one of the modern pioneers in the field of lexicography, the project has shown itself capable of assisting new lexicography units in African languages, as well as helping aspiring lexicographers to start their projects. In this regard, acquired skills of lexicographic strategic planning and management among other things, will enable the staff of the project to offer these important services. The project staff continually upgrade themselves in the field of lexicography by attending courses at the Bureau of the WAT and at SALEX. 


\title{
Zulu Dictionary Project
}

\author{
A.C. Nkabinde, Project Leader, Zulu Dictionary Project, University of \\ Zululand, Umlazi Campus, Isipingo, Republic of South Africa
}

\section{Aims and objectives}

The aims and objectives of the Zulu Dictionary Project can be summarised as follows:

- In the first place, to make a Zulu explanatory dictionary accessible to the speakers of the Zulu language and the public at large.

At the commencement of the project, no explanatory dictionary existed in Zulu. The need was obvious for social, educational, economic, technical, scientific and other purposes. The slow development of Zulu can largely be ascribed to the lack of explanatory dictionaries, which lead to a loss of confidence by the native speakers in the ability of Zulu to meet new demands and challenges. Anxiety, fear and doubt are created in the minds of the users of Zulu as to its capacity and suitability to meet new situations. This lack of confidence can be ascribed to the uncertainty as to the exact meanings of words, the correct use of words, and so forth.

- In the second place, to develop skills, to arouse interest, and to create a vocabulary for the definition of entries in the field of lexicography.

Lexicographic work requires appropriate tools. It is not sufficient to use synonyms or other known words to define entries to dictionaries. Definitions require a systematic, consistent and insightful treatment of entries. These must pervade the entire work. The use or creation of generic terms as a base of a definition could enhance the quality of definition. This calls for a critical evaluation of all definitions in order to excite and kindle the users' interest and imagination. The making of dictionaries is creative work. It is not a mere cataloguing of words.

- In the third place, to establish a database for linguistic research.

A dictionary is a good source of words, derivations, idiomatic usages of words, proverbs and other forms. It is a good facility for studies of phonology, phonetics, morphology and syntax. Above all it provides an excellent source for the study of semantics.

- In the fourth place, to provide an authoritative source of reference.

Ideally a dictionary serves as an arbiter to resolve differences in the interpretation of meaning. Since every lexicographer aims to produce a 
comprehensive definition of lemmata, entries in dictionaries are generally regarded as authoritative.

- In the fifth place, to record changes in the vocabulary of a language.

All languages are dynamic. They constantly incorporate new items of vocabulary. New vocabulary items include coinages and borrowings. Consequently, it is imperative to include the established, new vocabulary in the language. Obsolescence of words is also part and parcel of the existence of a language. Obsolete words deserve to be retained in a dictionary as they are indispensable in the study of historical linguistics and etymology.

- In the sixth place, to reinforce the definition of entries of flora and fauna.

Up till now many entries of flora and fauna are not adequately defined in the existing Zulu dictionaries. Comprehensive definitions of flora and fauna need to be given. The incorporation of botanical and zoological scientific terms in the entries will enhance their value.

- And lastly, to fulfil an educational need.

It is common knowledge that a dictionary is a learning aid. It fulfils a far greater need than simply providing meanings of words. It inculcates a habit of searching for and evaluating information and utilising it in a variety of new contexts. This contributes immensely to the development of independence in the use of information by the consultant of a dictionary.

\section{The History}

The Zulu Dictionary Project commenced on 1 December 1977. This was the first endeavour to produce an explanatory dictionary in Zulu. The project was started without a budget and without any provision for staffing. Three students were initially employed on an hourly rate and paid out of savings from the budget of the Department of African Languages.

In 1981, the Department of Education and Training approved the establishment of posts at lectureship level. Secretarial work for entering definitions on the computer was arranged on an ad hoc basis. The staffing position has not changed. It has accordingly not been possible to accelerate the tempo of work and embark on field work. The project leader was not able to devote much time to the task as he was involved in the administration of the University of Zululand for a considerable time.

Up till now, two publications, Isichazamasu 1 and Isichazamasu 2 in 1981 and 1985 respectively, have been produced by A.C. Nkabinde for use in schools. A more comprehensive version of this series was printed in 1998. 
Zulu lexicography dates back to 1857 with the publication of $A$ Zulu/Kaffir Dictionary by J.L. Döhne. This was followed by J.W. Colenso's Zulu/English Dictionary, A.T. Bryant's Zulu-English Dictionary, R.C.A. Samuelson's King Cetshwayo Dictionary, P.W. Wanger's Konversations-Grammatik der Zulusprache, ZuluEnglish Dictionary by C.M. Doke and B.W. Vilakazi, Woordeboek Afrikaans-Zoeloe Zoeloe-Afrikaans by A.M. Dekker and J.H. Ries and English and Zulu Dictionary by C.M. Doke, D.McK. Malcolm and J.M.A. Sikakana in 1958. Altogether eight major bilingual dictionaries existed when the Zulu Dictionary Project commenced its task. Many of these pioneers worked individually, on their own, without secretaries and without computers. But they did exceptionally good work. Subsequently, Afrikaans/Zulu Woordeboek met Engelse Vertalings by Ernst Kotzé and Patrick Wela and a monolingual Zulu dictionary, Isichazimazwi Sanamuhla Nangomuso by Sibusiso Nyembezi, have been produced respectively in 1991 and 1992. This is a good trend. There should be five, ten or fifteen dictionaries as is the case in many developed languages. One dictionary is not enough.

\title{
3. The current situation
}

The project has been battling to obtain financial assistance since its inception. It requires the services of at least two full-time workers and a full-time officer to capture data on the computer on an ongoing basis.

A major aspect of the dictionary encompassing the definition of flora and fauna had to be shelved because of lack of staffing. Similarly, it has not been possible to incorporate much new vocabulary because field work is necessary to gather information. The investigation and testing of vocabulary items from various geographic regions through field work had to be sacrificed. This means that important dialectal forms are lost.

\section{The State of Lexicography in Sesotho}

\author{
M.A. Moleleki, Department of African Languages, University of the Orange \\ Free State, Bloemfontein, Republic of South Africa
}

\section{Demographics}

Sesotho is a language spoken by $\pm 2,23$ million people in South Africa and by $\pm 1,98$ million people in Lesotho, giving a grand total of 4,21 million Sesotho speakers in the two areas. Of the 2,23 million Sesotho speakers in South Africa only about a million reside in urban areas. It can be accepted that more than $50 \%$ of the so-called urbanized Sesotho speakers function most effectively in Sesotho. If it is borne in mind that most of the nonurban Sesotho speakers hold 
their language in high esteem, it can be concluded that more than 1,3 million people in.South Africa need the Sesotho language for their day-to-day communication.

Furthermore, of the 1 million urbanized Sesotho speakers, the probabilities are that not more than 10 per cent is fully competent in a language other than Sesotho. If this estimate is correct, then $80 \%$ of the Sesotho speakers need their language for their survival.

The reasons for referring to statistical data are twofold. Firstly, it indicates that the majority of Sesotho speakers is not at all alienated from their language, and, secondly, it shows that the speakers rely heavily on their language for their effective functioning. The question can now be asked: how effective is the Sesotho language in addressing the needs of its speakers?

\subsection{Exotic Influence}

An earlier way of life has passed, and will never return. Modernization by way of industrialization, scientific and technological advancement, new ideas, concepts and philosophical thought pervades the world. To Sesotho speakers, modernization has always been exotic, both in terms of origin and expression. The initial providers of modernization were the French missionaries. Their influence is evidenced by nonnative Sesotho words such as pompong and potlolomente, loaned from the French words bon-bon and portmanteau respectively.

When Lesotho came under British rule, it was the turn of English to make its impact felt on Sesotho. Small wonder adoptives such as tjhentjha (to change) and joko (yoke) are used. The establishment of the Orange River Sovereignty (later known as the Orange Free State) led to coexistence between the Basotho and the Afrikaners. And it is no exaggeration to observe that no other nonSesotho language infiltrated Sesotho the way that Afrikaans did.

These influences stress the fact that from earliest times the linguistic situation in Sesotho has always been fluid, responding both to innovations and the new linguistic environment. The language never waited for either language experts or language practitioners to deliberate over its fate. It made and continues to make strides despite the intransigence of language purists.

\subsection{Sesotho Language Family}

It is necessary to place the term Sesotho in perspective, for this will have implications for the modus operandi of lexicographic projects. Sesotho is said to belong to the same language group as both Setswana and Sepedi. However, the said languages in fact share a common ancestor in the person of Malope, a Mohurutshe chief who broke away from the Barolong somewhere around Ethiopia during the 13th century. The three Sesotho languages should be seen 
as a family with a common origin rather than a language group based merely on shared affinities.

The gist of the argument is that a separatist approach to lexicographical research in the three languages will be as unfortunate as it would be undesirable. Closer co-operation among the three could yield far better results than at present. Of course this does not exclude closer ties among indigenous African languages per se. Also, differences that exist among the Sesotho languages should not be ignored.

The scenario sketched thus far illustrates how Sesotho, without the intervention of linguistic theoreticians, adapted and responded to changing circumstances from the very early stages of modernization.

\subsection{Early Lexicographic Activities}

With the foregoing constituting the background to this report, there can now be focused on the state of Sesotho lexicography. (Here the preparatory work done by Mr T.W.D. Mohapi must be acknowledged.)

The most important dictionary that can be mentioned is Adolphe Mabille's Sesuto-English Dictionary, published in 1876 at Morija in Lesotho. The work consisted of 158 pages. It came into existence in response to the missionaries' need to translate the Bible into Sesotho as well as to enhance effective communication with the Basotho. The dictionary underwent several revisions. The fourth edition appeared in 1911. This was enlarged by $\mathrm{H}$. Dieterlen of the French mission. It now contained 20000 words. In 1959 a reclassified, revised and enlarged edition by R.A. Paroz appeared. The dictionary is also available in the Sesotho orthography of the Republic of South Africa. Today this revision of more than thirty years ago continues to be the most useful and consulted work in Sesotho. It is for this reason that there should be dwelt at length on the nature of this work.

- As the name suggests, the dictionary is bilingual. Sesotho terms appear first and then their English translation equivalents.

The form of this dictionary reflects its initial thrust. Since the intended target audience of the missionaries was Sesotho-speaking, the missionaries first had to understand Sesotho before they could reach their converts; and the newly converted had to learn to express themselves in the language of the new faith so as to demonstrate that they were of a calibre different from that of the non-Christian stock - that they were educated and civilized.

And, also manifest in the structure of this very first Sesotho dictionary, is the erroneous impression created, be it by accident or design, that seemingly obscure Sesotho signifiers can only be explained in terms of English equivalents. The impression is created that Sesotho is incapable 
of self-explanation. Hence the practice of teaching Sesotho through the medium of English, or any other language for that matter.

- The dictionary is semilinguistic in nature. Only the sense and phonological features of words are to a certain extent considered, whereas the syntactic characteristics are completely ignored.

- The entries are arranged alphabetically in so far as the etymology of Sesotho terms is concerned. Thus the work is not user-friendly. It is structured by the presupposition that the user is very conversant with the structure of Sesotho. This implies that one looks up a lexical item one already partly knows by being familiar with its genesis. Needless to say, the dictionary is not meant for learners but for those who already have a sound competence in the language. The mere fact that only English translation equivalents are given rather than descriptions of the Sesotho lexes, seems to be based on the assumption that the user is steeped in English. English explanations are given only where a single English term equivalent for the Sesotho one cannot be found. The bilingual nature as well as the etymological bias of the dictionary largely favours a fully bilingual user. Furthermore, the synchronic nature of language is sacrificed at the expense of diachrony.

- The work is as comprehensive as it might be expected, given the circumstances surrounding its conceptualization. As indicated earlier, it was Christianity-oriented in its initial thrust. Subsequent editions only incidentally embraced the general world of the Basotho, especially their new work-places, the farms and the mines, as well as the cultural artifacts of the encroaching culture.

- It should be taken into account that the work was conceived and published during the 19th century and its subsequent revisions are almost as obsolete as the founding project itself.

In addition to the Sesotho-English Dictionary, there is L. Hamel's English-Southern Sesotho Dictionary published by the Catholic Centre of Mazenod in Lesotho in 1965. This work is very similar to Paroz's edition in terms of both substance and structure.

Whilst modernization has permeated the Sesotho-speaking people's entire lives, the conscious adjustment of Sesotho to this state of affairs has been both sporadic and haphazard, lacking in co-ordination and synthesis. A work that readily comes to mind under this category is A. Casalis' English-Sesutu Vocabulary published in 1894. It went through many editions. At leasi Casalis should be credited for his honesty: he makes no false claims to having written a dictionary. True to its name, the work is nothing else but an alphabetically arranged list of English words with their Sesotho counterparts. The reasons for selecting the words included in the vocabulary remains unclear. One might only hazard a guess that Casalis had to communicate in Sesotho the concepts and ideas embraced in the English terms. 
Although Casalis' work might not be worthy of the term dictionary as its title also reflects, it nevertheless begins to address a very pressing need in Sesotho and perhaps in other indigenous African languages as well. Since Sesotho has been left far behind in the advance to modemization, it presently lacks the capacity to express modern ideas and concepts. Thus the need for bilingual dictionaries based on English and for rendering Sesotho translation equivalents together with Sesotho definitions, has become more compelling than ever before. Stated differently, there was in the past and there exists today an urgent need for translation dictionaries in Sesotho.

\subsection{Language Committee / Language Board}

A series of Sesotho terminologies compiled over the years from 1954 to 1992 under the auspices of the then Department of Education and Training, should be viewed as attempts to address the problems faced by translators in fields as diverse as education, health and media. The Sesotho section of the South African Broadcasting Corporation also made its contribution. It used to have its own subcommittee working on terminology. These terminology lists were submitted to the Sesotho Language Committee which later became known as the Sesotho Language Board.

A few comments on the modus operandi of the Language Committee/ Language Board vis-à-vis terminology lists will suffice.

There was never any attempt to classify the terminology to be translated into its various fields of knowledge. Consequently, it rarely occurred to members to obtain certain kinds of expertise before attempting their own translations. Virtually all terminological areas were covered.

- No attempts were ever made to lay down guiding principles for the task at hand. Each term was not only seen as different from the rest, but also as unique, requiring a unique approach. Hence the work lacked both coherence and cohesion.

- The Committee sat for a period not exceeding eight days in one calendar year. And terminology was not its sole responsibility - it had other business such as the evaluation and prescription of literary texts. In this way the Committee never had sufficient time to concentrate on the intricacies of lexicography. It often happened that words had to be coined on the spur of the moment.

- There were no mechanisms in place to test the acceptability or not of the coined words among target users.

The then Language Boards operated under extremely difficult conditions. And, with the best of intentions on their part, their end products were inherently flawed. Nevertheless, they played a significant role by fulfilling a deeply-felt need. In short, these terminology lists warrant serious re-evaluation. 


\subsection{Individual Projects}

Projects were undertaken by individuals and by certain institutions.

J.A. du Plessis, J.G. Gildenhuys and J.J. Moiloa produced Bukantswe ya maleme-Pedi: Sesotho-Seafrikanse/Tweetalige Woordeboek: Afrikaans-Suid-Sotho in 1986. This dictionary consists of three parts. The first part contains Sotho terms with Afrikaans explanations, the second proverbs and common phrases in Sotho translated into Afrikaans, and the third Afrikaans terms with Sotho equivalents. Another publication is the Dictionary of Basic English: Southern Sotho edited by K.B. Hartshorne and published in 1984. This dictionary has two sections. The first section consists of English terms with different usages; the second part contains Sesotho equivalents corresponding to the English terms. Both these works could be regarded as dictionaries for learners, especially second-language learners.

Recently, in 1991, the Reader's Digest Association published a Multi-Language Dictionary written in seven languages. In fact, this is not a dictionary as the title purports, but a multilingual terminology list.

Work is also being done by the language unit at the Soweto Campus of the Vista University and by the Centre for Legal Terminology in African Languages at Sunnyside in Pretoria. These ventures require better co-ordination with other undertakings through networking.

The only Sesotho monolingual dictionary is the one written by F.Z.A. Matsela, and published by Macmillan Boleswa (Lesotho) in 1994. Its title is Sehlalosi: Sesotho Cultural Dictionary. As the name suggests, it focuses on a specific sphere of life, viz. culture. The Sesotho terms are further classified into subcategories such as the upbringing of children, songs and praises, religion and marriage, etc.

The terms are arranged alphabetically. The entries are based on the synchronic nature of the lexical items rather than on their historical roots. A descriptive approach was followed whereby each term is explained in Sesotho and its different nuances of meaning brought to the fore.

The author makes no pretence at exhausting the cultural field of the Basotho and yet his contribution is an eye-opener. Besides indicating possible future research directions, it caters for the needs of both learners and speakers of Sesotho. The work is also handy for researchers. Above all, it is userfriendly.

However, the dictionary does not provide information on for example tonology, etymology and syntax.

\section{The Road Ahead}

From the above overview of the state of lexicography in Sesotho, it becomes clear that Sesotho is in dire need of a monolingual dictionary, a dictionary which will affirm the status of Sesotho as a language whilst contributing towards the formation of a healthy mindset within the Sesotho personality. 
However, such a project should be seen as a long-term undertaking because of its magnitude and complexity. For medium- to short-term purposes it is necessary to work on:

- multilingual terminology lists, translating specifically from English to Sesotho. Such endeavours could alleviate the need for translation strategies.

- technical and specialized dictionaries, particularly in areas such as health, law and technology. The actual prioritization will be a matter of detail.

However, these medium- to short-term strategies should be seen as calculated strategies towards the ultimate goal - a Sesotho dictionary. The development should be from terminography to lexicography.

What is more, lexicography has grown into a demanding discipline with its own principles and considerations. Thus, for the envisaged projects, manpower exposed to the modern operational principles of lexicography is needed. People who can first exhaust the capacity of the Sesotho language before coining new terms are needed. Possibilities presented by linguistic permutations such as derivations, compounding, broadening of the semantic range as well as blending should be exploited to the full. A good mastery of the source language is also crucial.

Computer technology is one skill to be fully utilized. This will also enhance networking with possible resource instances.

\title{
5. Concluding Comment
}

Whilst dictionary-making is a highly sophisticated technical exercise, it is also one of the few opportunities where the indigenous speakers of a language have to be granted the right to take full control of their destiny. If tutelage becomes absolutely necessary, it should be at the language owners' discretion.

\section{The State of Lexicography in Setswana}

\author{
M.R. Malope, Emeritus Professor, Department of Setswana, University of the \\ North West, Mafikeng, Republic of South Africa
}

\section{Introduction}

Setswana as a language is used in the Republic of South Africa (where it enjoys official language status), Botswana (official language), Namibia (taught in schools up to Standard 4 only) and the South Western parts of Zimbabwe (where it is merely a means of communication and used sporadically). 


\section{Efforts at compiling Setswana dictionaries over the years}

The need to have a Setswana word-list and some sort of dictionary was felt very early in the contact situation between the Batswana and various groups such as missionaries, adventurers, colonists and later settlers and government and administrative officials in those areas inhabited by the Batswana.

In 1830 Robert Moffat published a Setswana version of the Gospel of St Luke, and at the back offered two pages of explanations of the more "difficult" words. These explanations can be regarded as the first small start of a Setswana dictionary. In the years following, Moffat, Edwards, Ashton, Hughes, Livingstone, Price and others produced word-lists as they worked on their translations and publications.

The first recorded published dictionary in Setswana, entitled Lokwalo loa Mahuku a Secwana le Seeneles, was compiled by Revd John Brown of the London Missionary Society in 1875-1876. This is a bilingual dictionary which consists of two sections, viz. a Setswana-English section (130 pages) and an EnglishSetswana section (145 pages). A second edition of this dictionary appeared in 1895 and was reprinted in 1914 and 1921 . The third edition was published in 1925 (in the orthography agreed upon in 1910) under the guidance of Revd J. Tom Brown and appeared under the title Setswana-English Dictionary. The third edition with a new preface appeared in 1965 and was reprinted in 1968, 1973, 1978, 1979, 1980, 1982 (twice), 1985, 1986 and 1987.

The fourth edition under the title Setswana-English-Setswana Dictionary was edited by Z.I. Matumo and was published by Macmillan Botswana in 1993. A Setswana orthography very close to the one current in the Republic of South Africa is used.

In 1976 Thanodi ya Setswana ya Dikole appeared under the editorship of Morulaganyi Kgasa, published by Longman Botswana. It was the first monolingual dictionary in Setswana prepared with schools as the target market. It consists of 125 pages.

J.W. Snyman, assisted by J.S. Shole and J.C. le Roux, edited the Dikisinare ya Setswana English Afrikaans Dictionary/Woordeboek published in 1990 by Via Afrika, the first trilingual dictionary in which Setswana featured. This dictionary prides itself on being rich in the vocabulary of Setswana "traditional life, botany, zoology, anthropology and ornithology".

Thanodi ya Setswana appeared in 1995 under the coeditorship of M.L.A. Kgasa and J. Tsonope, published by Longman Botswana. It can rightly be regarded as the successor of Morulaganyi Kgasa's Thanodi ya Setswana ya Dikole of 1976, and consists of 330 pages - the second monolingual dictionary in Setswana. This dictionary uses the present 1980 Botswana orthography, and also includes dialectal variants.

A Setswana monolingual dictionary project was started in 1984 at the Institute of African Studies, University of Bophuthatswana (now the University 
of North West), with J.M. Ntsime as editor up to 1987. From 1988 to 1995 D.M. Mothoagae was the editor, assisted by M.H. Zebediela, P.M. Rakgokong and T.J. Mabe. The first edition of this dictionary, to be entitled Thanodi ya Setswana, has been completed and is in the process of publication.

\section{The future}

These dictionaries are all useful in varying degrees to users of Setswana, depending on the individual's specific needs. However, they do not represent an exhaustive record and description of the Setswana vocabulary. A great deal of effort is still required to register the words that have appeared in various books and publications of Setswana, as well as words that are used in the context of various industrial activities such as mining and the manufacturing sectors. Setswana also needs a record and description of the Setswana vocabulary in the various fields of scientific study.

Efforts are afoot to establish a Setswana Language Body that will play a role in the process of establishing a Setswana Lexicographic Unit. So far, stakeholder organizations such as the Setswana Writers Association (Magopo), Setswana Association (representing teachers, lecturers, translators and the organised students in Setswana), the Setswana Bible Translators, the Bureau of Setswana Language and Culture and the Setswana Academic have expressed support for the establishment of a lexicographic unit for Setswana.

\section{The States of siSwati Lexicography}

\section{P.M. Lubisi, Department of African Languages, University of Zululand, KwaDlangezwa, Republic of South Africa}

\section{Introduction}

SiSwati belongs to the Nguni group of languages and is therefore closely related to Zulu. It is spoken and written in Swaziland and in the Republic of South Africa, especially in Mpumalanga. According to statistics, about $70 \%$ of the population of Mpumalanga is siSwati-speaking. In 1968 it became the national language of Swaziland, and in 1976 it was introduced as an official language in the former KaNgwane Swazi homeland. There has been close cooperation between the Swazis in the Republic of South Africa and those in Swaziland to develop siSwati as an official language. Before the South African Language Board for siSwati stopped functioning in 1996, joint meetings were regularly held with the Language Board of Swaziland. 


\section{Existing siSwati Dictionaries}

The first publication that can be called a dictionary is SiSwati Orthography, Terminology and Spelling Rules which appeared in 1980. This was followed in 1981 by the publication of D.K. Rycroft's Concise siSwati Dictionary (Pretoria, J.L. van Schaik). Research facilities for producing this dictionary were provided by the School of Oriental and African Studies at the University of London. The dictionary consists of two bilingual sections: the SiSwati-English part comprises 111 pages and the English-SiSwati part 73 pages. Because of its limited coverage and small size there are no illustrative examples, no special usage notes and no synonyms.

The first matriculation paper in siSwati was only dispensed in 1987. For years Swazis were compelled to study Zulu, which in practice hindered the progress and development of siSwati. Private schools situated in siSwatispeaking areas still prefer teaching Zulu instead of siSwati. Nevertheless, from 1976 onwards significant achievements were made in siSwati literature and textbooks, so that at the moment siSwati is offered as a degree subject by the University of South Africa and the University of Zululand.

SiSwati is still much neglected in the communication media. It does not appear in the SABC-TV news logo. Some of the announcers on the radio are not mother-tongue speakers of siSwati, which causes frustration among listeners of the siSwati radio Ligwalagwala. There is also little awareness of siSwati among the business community who prefer Zulu names for their businesses in spite of the fact that they are situated in siSwati-speaking areas.

\section{Conclusion}

SiSwati is in need of dictionaries of every kind: a monolingual dictionary, school and standard translation dictionaries, thesauri, idiom and proverb dictionaries, technical dictionaries, usage guides, etc. It is essential that siSwati lexicographic projects should be undertaken along with the development of the language itself. Dictionaries will certainly enhance pride and interest in the language. 


\title{
The State of Tshivenda Lexicography
}

\author{
A. Mawela, Northern Province Education, Arts, Culture and \\ Language Services, Pietersburg, Republic of South Africa
}

\section{Introduction}

The speakers of Venda are found mostly in Venda in the Northem Province, although some are found in other provinces, such as Gauteng, and a few in Mpumalanga, the Free State and North West Province, as well as in Zimbabwe.

\section{Existing lexicographic works in Venda}

Little has been done in the lexicographic field in Venda. At present there are only a few Venda dictionaries, all of them translating dictionaries, namely the Tshivenda-English Dictionary by N.J. van Warmelo published in 1937 by the Government Printer, Pretoria, and revised with the help of W.D.M. Phophi and published in 1989 as Venda Dictionary Tshivenda-English by J.L. van Schaik, Pretoria, the Trilingual Elementary Dictionary by P.J. Wentzel and T.W. Muloiwa, published in 1976 by the University of South Africa, Pretoria, and revised in 1982, and the Dictionary of Basic English: Venda by K.B. Hartshorne, published in 1984 by Educum, Johannesburg. The trilingual dictionary concentrates on words in common use in Venda, translating them into Afrikaans and English. In the foreword the authors comment on the lexicographic needs in Venda:

This work must be seen as a very modest attempt at complying with an urgent need ... It was found necessary to commence with compiling a preliminary work in the light of the fact that no Venda dictionary is available at present (Wentzel and Muloiwa 1976: xi).

There is another dictionary which has not been published yet, although it was completed several years ago. The title is Thalusa maipfi a Tshivenda (An Explanation of Tshivenda Words) by M.E.R. Mativha, N.A. Milubi and R.N. Madadzhe. The manuscript of this dictionary consists of three volumes: Two volumes contain Venda to English and one volume contains English to Venda concepts.

However, the printing of this massive work is long overdue. It would appear that publishers are not prepared to invest their money in publishing works which they believe will not generate any proceeds. Obviously it is presumed that very few people will be interested in buying a dictionary of this nature. This dictionary, however, is more up-to-date and treats a wide variety of concepts. Most of the terminology was collected from the Language Services Division. 


\section{Necessary lexicographic works}

\subsection{Subject (technical) dictionaries}

There is still a lot of work to be done in Venda in order to bring the language on par with other languages. Research work done so far has not resulted in different subject dictionaries such as medical, agricultural, economical, accounting, commercial and legal dictionaries.

In compiling subject dictionaries, researchers need to consider the figurative language used by traditionalists. Such special references are mostly found in medical or biological concepts. In most cases figurative concepts are utilised to avoid using the exact words which are regarded as taboo in Venda. A euphemism is for instance used if a woman fails to conceive. For example, "Musadzi uyu nowa yawe a i fari" which means, literally translated, "This woman, her snake does not hold or catch".

This way of expression is peculiar to Venda speakers, but it would not make sense to people who speak Venda as a foreign language. The figurative language which is commonly used in Venda has often resulted in people being treated or punished wrongly because of a lack of literature explaining such concepts. People have often been misdiagnosed in doctors' consulting rooms due to a lack of mother-tongue translators of Venda. For example, an old lady who says to the doctor "Ndi na mulenzhe", literally translated as "I have a leg", actually means "My leg is sore or painful". In courts people have been sent to jail for crimes they did not commit due to a misconception of words by interpreters who are foreign speakers of Venda. For example, an old lady was asked if she really did what she was accused of. She responded sarcastically saying "Nazwino", translated as "Of course". Yet the tone she used meant "No, I did not do it." Much as the concepts have to be taken into consideration, so also the tonal system existing in the language.

This shows the urgent need for idiomatic dictionaries in the language. This also indicates the need for research at grassroots level, where ordinary people have to be consulted.

\subsection{Dialectal (general) dictionaries}

Thorough research on different dialectal forms has to be undertaken, for there is a tendency among Venda speakers to reject certain words which they regard as borrowed. This retards the growth of the language. Venda speakers should stop looking upon the so-called standard dialect as the only correct dialect. All languages are at one stage or another influenced by languages with which they come in contact, for example the absorption of concepts such as "lobola" in English. 
In his book $A$ Linguistic Analysis of Venda (Pretoria, Via Afrika), George Paulos (1994: 8) echoes the notion that dialectal forms contribute to the growth of a language:

These speech differences that arise within a language may be due to various factors, for example, and this happens very often, the speech of a group is influenced by the language of an adjoining area, and as a result certain sounds or words of that language begin to creep in over a long period of time. These innovations then become established within that group and become part of their own language.

The standard dialect Tshiphani which the speakers of Venda recognise as the only correct dialect to be used, was first introduced by the missionaries in the area where the speakers of Tshiphani are concentrated. In his unpublished M.A. thesis The Toneme Patterns of the Venda Noun (Pretoria, University of South Africa), M.E.R. Mativha (1966:5) states:

This is the orthography in which the Bible and all Venda literary works are written. This orthography has remained stable for many years with only slight changes.

He also mentions that it was used by the Berlin Missionary Society in its church literature.

In addition to the dialectal variety in Venda, there is also the special way of speaking about royal families. For example: A chief does not drink from an ordinary calabash, called "khavho", but from a "ngwena", meaning "crocodile". A chief does not die like ordinary people for whom "u fa" is used, but he is compared to a lake which has gone dry: "mativha o xa".

When compilers take other dialects into consideration, monolingual dictionaries which define concepts of dialects in different areas will be made possible.

\section{Research work to be done}

Extensive research has to be done in different fields in order to keep pace with other advanced languages.

\subsection{Translation}

Translating dictionaries in other languages could be one way of meeting the lexicographic needs of Venda. New lexical items should be adopted as they are, with only a change in the spelling form which will follow the spelling rules of the translating language, in this case Venda. For example: tshitofu "stove", or vhurotho "bread". 


\subsection{Grassroots research}

Research has to be conducted at grassroots level, where researchers go out and actually mix with people from all ranks and walks of life to collect the latest concepts. For instance, researchers should go to sports fields, shebeens and different social gatherings where people use language in a relaxed and recreational atmosphere.

\subsection{Introduction of columns in newspapers}

A column in one of the national newspapers which introduces new concepts in different languages would help all South Africans to learn each other's languages and also to add to the growth of lexical items of the languages. This would familiarise speakers of other languages with Venda.

\section{Conclusion}

Stakeholders in the Venda language, who are probably not only Venda speakers, but hopefully all South Africans, should start researching to enable the growth of the language and close the wide gap which was created over a long period of slow development.

\section{The State of Xitsonga Lexicography,}

\section{D.I. Mathumba, Department of African Languages, University of South Africa, Pretoria, Republic of South Africa}

\section{Introduction}

It is possible to speak of lexicography only when a writing convention has been developed in a language. The Vatsonga are indebted to the missionaries of the Mission des Eglises Libres de la Suisse Romande, which later developed into the Mission Suisse dans l'Afrique du Sud, commonly known as the Swiss Mission in South Africa, for the conversion of Xitsonga into a written language. In July 1875 Revd Ernest Creux and Revd Paul Berthoud arrived in the then Northern Transvaal, which is today the northern part of the Northern Province, and settled at Valdezia. They immediately embarked on the immense task of committing Xitsonga to writing, but it was not until 1883 that the first publication, namely Buku ya TŠikwembo tŝin'we na Tisimo ta Hlengeletano, both Bible and hymns of the congregation, was published. 


\section{The emergence of Xitsonga dictionaries}

What could be regarded as the first dictionary in Xitsonga is a word list published by W.H.I. Bleek in 1856 under the heading "Lourenzo Marques" which was used because he was trying to give a word-list of the languages spoken around Lourenço Marques, the present Maputo in Mozambique. From this list one can extract those words which are Xitsonga. Among others there are tinyanyana "bird", fole "tobacco", dzana "hundred" and tandza "egg". A very interesting one is galloway for "pig". This was an attempt to put nguluve into writing.

The first Xitsonga dictionary was published in 1907. This was the pocket dictionary Tsonga / Shangaan / English - English / Tsonga / Shangaan, by the Revd C.H.W. Chatelain. Its second edition appeared in 1909. The current revised and enlarged sixth edition of the work is the English/Tsonga-Tsonga/English Pocket Dictionary, published in 1974 by Sasavona Publishers and Booksellers. The first product of creative writing to see the light was a novelette with the title Sasavona by D.C. Marivate, which was published in 1938. This booklet won him the prize of $€ 10$ in a competition of the International Institute of African Languages and Cultures in 1936.

An essential feature of the first edition of Chatelain's dictionary is that the first section contained an exposition of the grammar of the language, while the second section comprised the dictionary itself. An unfortunate omission in this dictionary is that the tone of the Xitsonga words was not marked. Although the marking of tone cannot be a hundred percent accurate, it is essential to indicate this feature because Xitsonga is a tone language. Only the basic tone should be marked and in the introduction a brief note on Xitsonga tone assimilation should be included.

The next dictionary to be published was by Revd R. Cuénod, Tsonga/ English Dictionary, which appeared in 1967. As the name indicates, the entries are Xitsonga words followed by their English equivalents. There are no reversed entries in English with equivalents in Xitsonga. This is a much larger work than Chatelain's dictionary and has since been reprinted five times.

A good feature of this dictionary is the introduction in which the author gives a brief outline of the grammar of the Xitsonga language. The tone of the Xitsonga entries is also marked. Unfortunately, there are many instances where the copulative tone has been used and this does not reflect the tone of the word when it is in isolation. The author has also included an appendix of a selection of terms created by the Xitsonga Language Committee. This is a useful addition and forms the rudiments of a technical dictionary.

In 1983, K.B. Hartshorne published the Dictionary of Basic English, with an appendix containing the Xitsonga equivalents for all the English entries in the dictionary. This is a valuable dictionary which was compiled for pupils who studied English as a second or foreign language. 
Alongside these developments were the activities of the Education Department to develop the African languages to a higher level of expressiveness so that they can be used as media of instruction at school.

Language Committees and Language Boards were established to cater for the planned development. This resulted in terminology lists which were published and updated from time to time. The last of these for Xitsonga was the Tsonga Terminology and Orthography, published in 1980. In spite of some shortcomings, these terminology lists serve as useful reference sources for learners of the Xitsonga language.

Still in the pipeline are two Xitsonga dictionaries. Modern Xitsonga/English Dictionary compiled by E.J.M. Baumbach and D.I. Mathumba is currently at Pharos Dictionaries. The popular Xitsonga dictionary by Malungana, edited by D.I. Mathumba, is also to be published by Pharos Dictionaries.

A common denominator of these dictionaries is the fact that they are all bilingual dictionaries. Furthermore, they are all biased towards English, except the terminology list of the Department of Education, which is trilingual, Afrikaans occupying the middle column of the pages. This also points to a bias towards English, since no Afrikaans headwords feature. In spite of the strong inclination towards English, it is nevertheless not easy for an English-speaking person to use these dictionaries in learning the Xitsonga language, due to their one-sidedness. Only Chatelain's dictionary reverses the languages within one and the same dictionary.

\section{The needs}

From the foregoing exposition it is clear that the Xitsonga language still lacks many types of dictionaries that are necessary for its development and empowerment so that it may take its rightful place as an official language in South Africa.

Bilingual dictionaries such as those mentioned above, are mainly useful to English speakers who wish to learn Xitsonga, and vice versa. They do not contribute much to the development of the Xitsonga language.

Monolingual dictionaries, which Xitsonga lacks, have to fulfil this need. The expressive level of the language is greatly enhanced when concepts are explained in Xitsonga itself. Another area in which Xitsonga has lagged behind is that of bilingual dictionaries involving the Afrikaans language.

Since South Africa is a multilingual country and the people of the country opted for a policy of multilingualism, it is essential to have multilingual dictionaries. There are two such dictionaries but Xitsonga has not been included in them.

There is much talk today about the harmonisation of technical terms. This is a clear indication of the significance of a technical vocabulary. Xitsonga does not have any dictionaries in this area either. Closely related to this lack is the lack of dictionaries of literary and linguistic terms. If Xitsonga is to develop 
into an effective medium of instruction in the language itself, up to the highest level, dictionaries of linguistic and literary terms are indispensable. Such dictionaries will minimise or eliminate the use of different terms for the same concept, in the same country, in the same language, and will also enhance easy communication and exchange of information.

Lexicographers are not there to coin words. For this purpose terminographers are needed. When the terms have been developed, lexicographers systematise them into various types of dictionaries for different people to consult. To these dictionaries can be added thesauruses of synonyms, antonyms and so forth, as well as school and children's dictionaries. Spell checking programs for the computer are also needed.

Besides dictionaries themselves, there are other lexicographic needs experienced in Xitsonga. Xitsonga does not have specially trained people to be engaged in the production of Xitsonga dictionaries. At present this task is undertaken by personnel in tertiary institutions, especially universities. Understandably, these academics do not have enough time to devote to the compilation of dictionaries, with the result that there are considerable delays in the publication of these works.

To conclude, it can be said that although Xitsonga has dictionaries, they are all bilingual dictionaries which are heavily biased in favour of English. There is therefore a great need not only for new dictionaries, but also for expert lexicographers to produce them. 